\title{
Does E-Procurement Matter for Economic Growth? Subnational Evidence from Australia
}

\author{
Thomas Emery $^{*} \quad$ Lela Mélon ${ }^{\dagger} \quad$ Rok Spruk
}

\begin{abstract}
We examine the impact of e-procurement on economic growth. To this end, we exploit an ambitious implementation of large-scale mandatory e-procurement platform in New South Wales and Western Australia. By matching pre-reform growth dynamics and its covariates with the rest of the world, we provide a plausible source of variation in growth that allows us to build a counterfactual growth scenario in the hypothetical absence of the reform. Using a donor of more than 100 countries in country-state matched balanced sample, our evidence highlights a mixed impact of mandatory e-procurement on growth. We find that the institutional quality of governance and policy implementation underlines the magnitude of the growth effect. In particular, our findings contrast a significant positive impact of the mandatory eprocurement on the economic growth of Western Australia with a zero impact of the similar reform in New South Wales. We argue that this contrast arises from the differences in transaction costs, quality of governance, and strength of regulatory oversight that either foster or hamper the opportunities for corruption. The estimated impact of reform is robust across a multitude of spatial and temporal placebo studies, choice of samples and does not seem to be driven by pre-existing shocks or prevalent economic conditions.
\end{abstract}

Keywords: e-procurement, economic growth, Australia JEL Codes: C13, C21, D73, P51, O43, O47

\footnotetext{
${ }^{*}$ Research Fellow, Business School, University of Western Australia. E: thomas.emery@uwa.edu.au

$\dagger$ Marie Curie Post-Doctoral Fellow, Faculty of Law, University Pompeu Fabra, Barcelona. E: lela.melon@upf.edu $\ddagger$ Assistant Professor, School of Economics and Business, University of Ljubljana, Slovenia. E: rok.spruk@ef.uni-lj.si
} 


\section{$1 \quad$ Introduction}

The notion that the set of institutions that supports the rule of law, secure property rights, and low-cost enforcement of contracts is crucial for sustained long-run growth and the wealth of nations has become widely accepted (North 1987, Knack and Keefer 1995, Hall and Jones 1999, Easterly and Levine 2003, Roland 2004, Acemoglu et. al. 2005, Easterly and Levine 2016, Gorodnichenko and Roland 2017). Most scholars concur that economic growth and inclusive long-run development can hardly be sustained in the presence of weak rule of law and pervasive corruption (Mauro 1995, Méon and Sekkat 2005, Campos et. al. 2012), low-quality administration of justices (Smith 1776, Torstensson 1994, Posner 1998, Ippoliti et. al. 2015, Marciano et. al. 2019), and costly enforcement of contracts (Olson 1992, Rajan and Zingales 2001, Prados de la Escosura and Sanz Villaroya 2009). Moreover, ineffective government administration has been oftentimes emphasized as one of the crucial policy distortions that impedes the economic transactions, distorts the incentives to engage in productive economic activities, and undermines the economic growth potential (Przeworski et. al. 1995, Rodrik 2000, Angelopoulos et. al. 2008, Afonso et. al. 2010, Fátas and Mihov 2013). Low-cost enforcement of contracts and highly effective government administrations are significantly more likely to promulgate growthenhancing policies free of policy distortions that protected the vested interests (Parente and Prescott 1998) whereas countries without such framework are condemned to economic stagnation and underdevelopment (Scully 1988, Alesina and Perotti 1994, Alesina et. al. 1996, De Haan et. al. 2006, Coatsworth 2008).

The conventional wisdom tells us that the regulatory barriers are of the key causes of large and persistent income per capita differences. Many of these barriers protect the interest groups that impede the production of goods and services, discourage the adoption of more efficient 
technology and may lead to the slowdown of economic growth. Hence, productivity differences are largely the result of these country-specific policies, distortions and barriers to entry that impose adverse constraints on the labor supply and the application of better technology. In addition, we know that legal institutions have a profound impact on the efficient use of technology and may either help or hurt economic growth (Williamson 1994, Levine 1998, Berkowitz et. al. 2003, Arruñada and Garoupa 2005, Castro et. al. 2009, Cooter and Schäfer 2012).

In this paper, we examine the effect of implementing e-procurement in the government administration on economic growth. To this end, we exploit the introduction of e-procurement take-up by New South Wales in 2002 and Western Australia in 2000 as a source of variation in long-run growth. Both states implemented a large-scale public e-procurement system to move the public-sector procurement process online by developing an ambitious e-procurement portal. Afterwards, numerous irregularities and issues of corruption by the local councils related to eprocurement implementation were found by the audit inspections in New South Wales compared to e-procurement implementation in Western Australia, which has been acclaimed for its rigor and absence of irregularities, hence leaving fewer opportunities for corruption. We estimate the economic growth impact of implementing e-procurement for both states by using synthetic control methodology (Abadie et. al. 2010, 2015) where we match them synthetically with other countries without the similar e-procurement reform.

Drawing on a sample of more than 100 countries for the period 1950-2016, our results indicate large and pervasive growth gains from introducing e-procurement in Western Australia and no effect of the similar reform on the economic growth of New South Wales. Prior to the 
reform, the long-run growth path of both states appears to be well captured by growth trends of countries at the parallel stages of development. After the reform, Western Australia's long-run growth tends to break off its synthetic control group with little evidence of pre-existing trends. Several placebo checks confirm the statistical significance of the growth effects of e-procurement for Western Australia in contrast to weak and insignificant impact of the reform in New South Wales.

The rest of the paper is organized as follows. Section 2 reviews the policy background. Section 3 presents our identification strategy. Section 4 discusses the data and samples. Section 5 proceeds with results and robustness checks. Section 6 concludes.

\section{$2 \quad$ Background}

Australia has varying government public procurement policies, managed independently at the three levels of government, national (federal), state/territory (sub-national) and local (municipal). The transition towards e-procurement in Australia began with the federal government's adoption of the UNSPSC standard (created by the United Nations in 1998). A previous national parliamentary inquiry estimated broadly that the combined total of federal, sub-national and municipal procurement totaled approximately 30 percent of GDP ${ }^{4}$ (COA 1994). Due to constitutional limitations, uniformity in procurement policies across governments has been slow to implement outside of public monopolies like rail, transport and electricity generation/distribution (Callender and Schapper 2007).

\footnotetext{
${ }^{4}$ There was no reliable means of calculating this figure accurately at the time.
} 
The vertical fiscal imbalance within the federation ${ }^{5}$ decreases spending autonomy in the State Governments, giving the federal government greater scope to coerce the States into adopting a uniform model through funding arrangements. Municipal governments in Australia are defined and administered through state legislation, not constitutionally mandated. They accrue around half of their income levying property taxes and are otherwise reliant on state and federal grants, limiting their autonomy in spending. States are bound through the Competition Principles Agreement ${ }^{6}$ to ensure their public authorities comply with federally consistent competitive neutrality principles and similarities in administrative goals of equity, probity, transparency and value for money exist across jurisdictions. The key differences relate to degree of centralisation, purchasing-local clauses, and the drive for e-procurement (Callender \& Schapper 2007 p.26).

The NSW Government sought to develop a single e-Marketplace in April 2001 to reform the procurement activities and introduced a comprehensive Electronic Procurement Implementation Strategy in 2002 (DPWS, 2002). At the time, annual state government expenditure was approximately $\$ 17$ billion on the procurement of capital assets, maintenance, and goods and services. Multinational company Logica won the bid to became Australia's largest online procurement system. The strategy was ineffective, however, and saw further reforms in 2006 and 2011.

A 2011 financial audit by the NSW Auditor General found e-procurement and e-tendering across the government agencies to have "very poor compliance", partially owing to the number

\footnotetext{
${ }^{5}$ The Federal government has the greatest revenue raising powers through income tax, whilst the States account for the majority of operating demands and are therefore reliant on federal grants to meet these obligations.

${ }^{6}$ Created on 11 April 1995 by the Commonwealth, the Territories and the States
} 
of government policy requirements, guidelines and exemptions (Audit Office of New South Wales, 2011 p.18). Additionally, the Independent Commission Against Corruption reported in 2010 that "approximately $30 \%$ of our public inquiries make findings of corrupt conduct related to NSW government procurement." (ICAC 2011).

\subsection{History}

The Western Australian procurement reform began in 2002 and was independently funded and implemented by the State government after a Functional Review Taskforce estimated over $\$ 100$ million per annum could be saved through a whole-of-government approach to procurement (Byrne, 2013 p.397). The reforms focused on "the combined strategies of developing electronic marketplaces, enhancing the skills of procurement staff, and improving procurement evaluation processes." (Callender \& Schapper, 2007 p.25). This began with updating the State's eprocurement policy to the UNSPSC standard, which facilitated the sharing of tenders between all Australian governments and creating the opportunity for Western Australian Suppliers to bid for national tenders.

The Western Australian Government spent approximately $\$ 5.7$ billion in the 2002-03 financial year ${ }^{7}$ on goods and services, facilities management and capital works. Central to the eprocurement system was the GEM tool, brought online in 2000, which had platforms for tendering, purchasing and contracting.

The Gem Tendering platform was already a mature product, adapted from the previous Government Contracting Information Bulletin Board and was effective for online tendering at

\footnotetext{
${ }^{7}$ In $2003-04$ it was $\$ 6.6$ billion, which is $7.4 \%$ of Western Australia's GSP ( $\$ 89.2$ billion).
} 
the outset. Goods and services accounted for $\$ 3.4$ billion, of which approximately $\$ 1.9$ billion was for purchases above $\$ 50,000$ and required public tendering.

The remaining $\$ 1.5$ billion was spent on purchases below the public tender threshold and came under the purview of Gem Purchasing, an online marketplace for high volume, low value purchases. As $90 \%$ of purchases were less than $\$ 5,000$, and $80 \%$ were less than $\$ 500$, efficiency savings were significant. The Functional Review Implementation Team had previously found the transaction cost for individual items to be greater than the value of the item itself "eg paying $\$ 100$ in transaction costs to buy an item worth $\$ 75 "$ - WA 2003 Procurement Synopsis. More competitive prices were secured through aggregated buying in leverage the WoG buying power. The platform also created online catalogues and a registry of suppliers, where government agencies could obtain quotes and approvals, "place orders and acknowledge the receipt of goods and services". Benefits were also realized in the renegotiation of whole-of-government common use contracts (CUCs, CUAs), where purchasing totaled $\$ 840$ million in the same year (DTF 2003). A review was conducted by the DTF in 2003 after initial poor uptake of Gem Purchasing, which found that successful marketing had ensured adequate suppliers were using the platform, however, buyer adoption (government agencies) was unmandated, underdeveloped and resultingly low. Competing priorities and other e-procurement options led to many agencies adopting a wait-and-see position (DTF 2003 Gem p.7).

Gem Contracting was created to offer benefits in the standardization of contract development and management for high value (above $\$ 50,000$ ), low volume purchases. Probity meant generally all contracts over $\mathrm{AU} \$ 50,000$ were required to face public tender. The process was often reviewed by State Supply Commission and State Tenders Committee, and the Office 
of the Auditor General reviews samples of public tenders regularly. (Callender and Schapper 2007). Other benefits included "an automated workflow for guidance throughout the life of a contract, best practice guidelines, and a document repository."

In February 2003, the Department of Industry and Technology was absorbed between the Department of the Premier and Cabinet and the Department of Treasury and Finance (DTF). An "Office of E-Government" was created within the Department of Prime Minister and Cabinet to oversee the policy reforms, which included the grounding of the Government Electronic Market (GEM), to be managed by the DTF. ${ }^{8}$ A Business Solution and Implementation Plan was drafted by the DTF with support from Deloitte, and endorsed by Cabinet in December 2003.

Several initiatives ensured the policy's successful implementation. The performance and outcome of the implementation was measured at the conclusion of each financial year from 200405 using a balanced scorecard approach, which resulted in publicly available Benefit Realisation Reports that were reviewed by State Parliament. A follow-up report by the DTF found quantifiable procurement savings of $\$ 477$ million between July 2003 and June 2008 with a net investment of $\$ 31.4$ million (DTF 2008). These do not account for the compounding savings and efficiencies.

\subsection{Improvements}

The procurement reforms saw improvements in four major areas, underpinned by good policy and implementation: governance, human capital, policy and process and technology. Direct savings were most prevalent in CUAs, agency specific spend, and building maintenance and

\footnotetext{
${ }^{8}$ The system was updated in July 2003 and ultimately replaced in 2007 with a Shared Services ERP system.
} 
transportables (DFT 2008, p16). Agency specific spend is the purchasing of government departments with their own budget approval frameworks, the largest of which is the Department of Health (43\% of total agency specific spend), which achieved estimated contract savings of $\$ 34.5$ million in 2007-08 as a result of the reforms (DFT 2008, p16). The accumulated incremental improvements in many agencies coincided with economies of scale through standardisation and mandated whole-of-government purchasing procedures, delivering significant economic gains.

The governance aspect of the reform saw improvements in the creation of specialist governing bodies for advice, client relations, tender review and stewardship of the implementation. New database systems were implemented for the collection and analysis of procurement data, including qualitative performance measurement through periodic customer and stakeholder satisfaction surveys. Procurement reporting was improved significantly, including whole-of-government annual procurement reports measuring benefits and outcomes of the program against a balanced scorecard, e.g. Who Buys What, and the Procurement Reform Benefits Realisation Reports. Also, an annual awards program, Innovation in Procurement Treasurer's Awards, was created to promote best practice through recognition.

The improvements in human capital in the sector included the creation of a single team of 280 procurement practitioners with knowledge of the policy standards, located across 32 government agencies. Staff development and knowledge networks were the prioritised, and graduate and lateral recruitment programs were developed alongside new staff attraction and retention initiatives. Procurement gained recognition as a profession within the public sector through post graduate studies in Strategic Procurement at a state university and accreditation by the Australian Procurement and Construction Council (APCC), and the Chartered Institute 
of Purchasing and Supply (CIPS). This occurred in conjunction with training programs and DTF run workshops targeting both procurement practitioners and agency buyers on how to scope and better manage consultancy contracts.

The policy and processes were improved through three successive reviews aimed at modernising and streamlining the policy, the culmination of which was a comprehensive 'practice guide' for public servants engaged in buying. The tendering and contract documentation were standardised across the public sector. Significant improvements in efficiency were attributed to increasing the direct purchasing limit ${ }^{9}$ to $\$ 5000$ and increasing the public tender threshold from $\$ 50,000$ to $\$ 150,000$. This was increased to $\$ 250,000$ for pre-qualified suppliers, i.e. CUAs, the use of was mandated for most purchasing within the Perth region. Over 50 new and redesigned CUAs, changed to 'pick and buy' contracts constituted savings of an estimated $\$ 99$ million in the 2007-08 financial year. "the Gateway Review Process - a project assurance methodology aimed at improving the delivery of major public sector infrastructure and IT projects in particular."10 The use of purchasing cards for low value purchasing increased efficiency and transparency, increasing the number of transactions by approximately $70 \%$ between 2005 and 2008 , and increasing the value of purchases from $\$ 75$ million to $\$ 160$ million. The 2008 DTF review of the reform found in the Policy and Process dimension alone, efficiency benefits are conservatively estimated at $\$ 21.5$ million for the 2007-08 financial year.

The technological upgrade began with an initial review of all existing electronic systems used for procurement and the removal of duplication across the sector. These were then replaced

\footnotetext{
${ }^{9}$ Not required to obtain multiple quotes.

10 "The Gateway Review consists of a series of structured Reviews that examine procurements at six key decision points (or gates) in the procurement cycle. These gates are Strategic, Business Case, Procurement Strategy, Tender Review, Pre Commissioning and Post Implementation."
} 
"with new whole-of-government applications covering e-procurement, information management, contract development and management, and expenses management." This included a new Contract Development and Management System and "new online procurement sourcing tools such as the Government Contract Directory using e-book technology, the innovative e-Decision Aid tool for use with CUAs involving a significant level of product choice." The GEM platforms were replaced through a systematic development of fit-for-purpose tools such as iProcurement and online Purchasing modules of the Shared Services ERP system. Training and support for staff was prioritized during the transition. Through a rigorous pilot project, best practice online reverse auction technology was developed for range of different procurements and extended into other public sector procurement activities.

Concurrently, State Government expenditure on services increased from AUD\$3.99 billion to AUD $\$ 6.14$ billion between the fiscal year 2000-01 and 2004-05 (Callender \& Schapper 2007). ${ }^{11}$ The previous procurement legislation dictated by the State Supply Commission Act 1991 and required all WA State Government public authorities to achieve a minimum of $80 \%$ local purchasing, where feasible. Western Australia concurrently introduced a Support Local Industry policy in 2001 and a Buy Local policy in 2002, however these were not supported by incentives for agencies (Callendar and Schapper 2007). The only likely clause was the requirement to include an evaluation of local content in any tender above AUD $\$ 750,000$.

The literature on the economic effects of e-procurement policy changes in the Australian context are sparse, especially at the State level. Annual Procurement Reform Benefit Realisation Reports outlined the quantitative and qualitative changes using the balanced scorecard approach,

\footnotetext{
${ }^{11}$ Government expenditure on goods did not change significantly over that period.
} 
however, these focused on immediate benefits and subsequent reforms shortly thereafter have made it difficult to attribute medium-term economic improvements to specific iterations of the reforms. The 2008 reform review by the Department of Finance and Treasury estimated $\$ 477$ million were saved between 2003 and 2008, with a total reform implementation cost of $\$ 31.4$ million over (DFT 2008, Callender and Schapper 2007, Byrne 2013).

\section{$3 \quad$ Identification strategy}

Our aim is to examine the contribution of adopting e-procurement to economic growth consistently. To this end, we exploit the pre-adoption economic growth dynamics between New South Wales and Western Australia and the rest of the world to compute the missing counterfactual growth scenario in the hypothetical absence of the e-procurement. We use the synthetic control estimator originally proposed by Abadie et. al. (2010, 2015) which has been used extensively in evaluation of the effect of policies and external shocks on a broad array of economic outcomes.

Consider a simple canonical panel with with $i=1,2, \ldots N$ countries together with New South Wales and Western Australia observed for $t=1,2, \ldots T$ time periods. Suppose $J \in\{i=1,2\}$ denotes the treatment set, which consists of New South Wales and Western Australia. Let $Z$ be an indicator that $j$-th region is directly affected by the adoption of eprocurement. Hence, we assume that the full set of $\mathrm{J}$ region are treated by the adoption of eprocurement that takes place at time $T_{0}<T$ whereas the control group receives no treatment

which implies that $Z_{i}=0$. In total, we have $N_{1}=\sum_{j=1}^{J} Z_{j}$ treated regions and $N_{0}=N_{1}-N_{0}$ control countries in the donor pool. 
Our outcome of interest to capture economic growth trends is per capita income. We use the potential outcomes framework proposed by Rubin (1974) and assume a well-defined treatment that excludes interference between regions and their control countries. The potential per capita income in New South Wales or Western Australia in interference-adjusted control samples is $y_{i, t}(0)$ and $y_{j, t}(1)$, which leads to the following observed outcomes:

$$
y_{i, t}=\left\{\begin{array}{lll}
y_{i, t}(0) & \text { if } Z_{i}=0 & \text { or } t \leq T_{0} \\
y_{j, t}(1) & \text { if } Z_{j}=1 & \text { and } t>T_{0}
\end{array}\right.
$$

Let $\mathbf{X}$ represent pre-war per capita income and covariates associated with long-run growth and development that corresponds to $N_{0} \times T_{0}$ matrix where $\mathbf{X}_{0}^{\text {Control }}$ denotes the full set of covariates for the countries in the control sample and $\mathbf{X}_{j, 1}^{N S W / W A}$ is the set of pre-reform outcomes and covariates in New South Wales and Western Australia. The treatment effect of eprocurement on growth is given by:

$$
\lambda=\lambda_{1 T}=y_{1}\left(Z_{j}=1\right)-y_{1}\left(Z_{i}=0\right)=y_{1}-y_{0}
$$

We construct the counterfactual growth and development trajectory by imputing the missing potential outcome for the New South Wales and Western Australia after the adoption of eprocurement as a weighted average of the outcomes in the control sample. By following Abadie and Gardeazabal (2003) and Abadie et. al. (2010), the set of weights used to construct the counterfactual outcome is defined as a solution to the constrained optimization problem: 


$$
\min _{\mu} \sum_{t=1}^{T_{0}}\left(\mathbf{X}_{j, 1}^{N S W / W A}-\mathbf{X}_{i \notin j, 0}^{\text {Control }} \boldsymbol{\mu}\right)^{2}
$$

where $\sum_{i=1}^{n} \mu_{i}=1$ and $\mu_{1} \geq 0$ with $i=1,2, \ldots N$ and the minimization constraints set the limit of $\mu$ to the $N_{0}$ simplex such that $\mu \in \Delta^{N_{0}}$. The weights from Eq. (3) minimize the imbalance in covariates and pre-treatment outcomes between New South Wales and Western Australia and their synthetic control groups. If the exact balance can be achieved such that $\sum_{t=1}^{T_{0}}\left(\mathbf{X}_{j, 1}^{N S W / W A}-\mathbf{X}_{i \neq j, 0}^{\text {Control }} \mu\right)=0$, the synthetic control estimator for the treatment effect of interest is asymptotically unbiased. Country-level weights that yield the exact balance may be achieved if the treated region is inside the convex hull of the control sample.

We also assume that there are $\mathrm{K}$ latent time-varying covariates $\gamma_{t}=\left\{\gamma_{k t}\right\}, k=1,2, \ldots K$ with $\max _{k t}\left|\gamma_{k t}\right|<L$, where $K$ will be small relative to $N$. Each country has a vector of factor loading denoted by $\boldsymbol{\theta}_{i} \in \mathbb{R}^{K}$. This implies that the per capita income in the control group is a weighted average of these factors plus the additive error term:

$$
y_{i t}(0)=\sum_{k=1}^{K} \theta_{i k} \gamma_{k t}+u_{i t}
$$

where $u$ denotes the random error term, and $\gamma$ represents the full set of pre-reform outcomes and covariates that may be collected into the matrix $\gamma \in \mathbb{R}^{T_{0} \times K}$. By invoking temporal and crosssectional independence in the random error term as a sub-Gaussian random variable with a certain scale parameter, we further assume that the latent time-varying factors are orthogonal 
and that treatment assignment variable $Z$ is ignorable given the country-level factor loadings which implies that:

$$
\mathrm{E}_{u_{T}}\left[y_{i}(0), \theta_{i}, Z_{i}\right]=\mathrm{E}_{u_{T}}\left[y_{i}(0), \theta_{i}\right]
$$

where under the linearity in parameters assumption and ignorable treatment assignment for given $\theta_{i}$, the synthetic control estimator that balances the pre-procurement reform outcomes and covariates between New South Wales, Western Australia and the control group, yields a reasonably unbiased estimate of $y_{1}(0)$ if the ex-ante observed differences in outcomes are covariates between the treatment and control samples are sufficiently small to rule out large approximation errors. The bias of the weighting estimator with the series of non-negative and additive weights is (Ben Michael et. al. 2018):

$$
\begin{aligned}
& E_{\varepsilon_{T}}\left[y_{1}(0)-\sum_{Z_{i}=0} \mu_{i} y_{i}\right]=\left(\theta_{1}-\sum_{W_{i}=0} \mu_{i} \theta_{i}\right) \cdot \gamma_{T}= \\
& =\frac{1}{T_{0}}\left(\gamma^{\prime} \mathbf{X}_{j, 1}^{N S W / W A}-\sum_{Z_{i}=0} \mu_{i} \gamma^{\prime} \mathbf{X}_{i \notin j}^{\text {Control }}\right) \cdot \gamma_{T}-\frac{1}{T_{0}}\left(\gamma^{\prime} u_{1}-\sum_{Z_{i}=0} \mu_{i} \gamma^{\prime} u_{i}\right) \cdot \gamma_{T}
\end{aligned}
$$

where the first term captures the imbalance in covariates, and the second term captures the approximation error. Notice that the approximation error is typically small if the pre-treatment period $T_{0}$ is sufficiently large. Following Dube and Zippner (2015), Ferman and Botosaru (2019) and Aldhikari and Alm (2016), we avoid using the average of pre-treatment outcomes in our specification. Instead, we further minimize the covariate imbalance by deploying the four lags of 
the outcomes into our key synthetic control specification, allowing us to fully exploit the timeseries dynamics in per capita output to further unravel the treatment effect of adopting eprocurement on economic growth.

Let $W=\left(w_{2}, \ldots, w_{J+1}\right)$ be a vector of weights with $w_{j} \geq 0 \forall j$, where each element of $W$ represents a potential synthetic control unit. For a given $W$, the per capita income for a synthetic control at time $t$ is:

$$
\begin{aligned}
& \ln y_{W, t}=\sum_{j=2}^{J+1} w_{j} \ln y_{j, t}=\gamma_{t}+\theta_{t}\left(\sum_{j=2}^{J+1} w_{j} X_{j}\right)+ \\
& \lambda\left(\sum_{j=2}^{J+1} w_{j} \mu_{j}\right)+\left(\sum_{j=2}^{J+1} w_{j} \varepsilon_{j, t}\right)
\end{aligned}
$$

where it is assumed that $\exists W^{*}$ is such that the synthetic control is set to match the treated unit in the pre-breakdown period so that $\sum_{j=2}^{J+1} w_{j}^{*} Y_{j, t}=Y_{1, t} \forall t \in\left\{1, \ldots, T_{0}\right\}$ and $\sum_{j=2}^{J+1} w_{j}^{*} X_{j}=X_{1} \cdot{ }^{12}$ If the conditions are met, the synthetic control associated with $W^{*}$ replicates the missing counterfactual. Hence, an approximately unbiased estimator of $\lambda_{1, t}$ is then given by:

$$
\hat{\lambda}_{1, t}=\ln y_{1, t}-\sum_{j=2}^{J+1} w_{j}^{*} \ln Y_{j, t}=\ln Y_{1, t}-\ln Y_{W^{*}, t}
$$

\footnotetext{
12 It is furthermore assumed that $\sum_{t=1}^{T_{0}} \Omega_{t}^{\prime} \Omega_{t}$ is non-singular. Then, for all $t>T_{0}$, $E\left[\ln y_{j, t}^{N}-\sum_{j=2}^{J+1} w_{j}^{*} \ln y_{j, t}\right] \rightarrow 0$ as $T_{0} \rightarrow \infty$ or if $T_{0}$ is large relative to the post-treatment period.
} 
where a nested weighing matrix is used to minimize the root-mean-square prediction error and compute a reasonably unbiased synthetic match of the treated unit. Compared with differencein-differences analysis, the synthetic control method imposes less restrictive functional assumptions on the estimation process. Under a data-driven approach to the counterfactual estimation, $W^{*}$ forces the data to exhibit similar trends in the pre-breakdown period, because the validity of the synthetic estimates crucially hinges on the similarity of pre-reform growth trends.

\section{$4 \quad$ Data}

Our dependent variable is real per capita GDP adjusted for purchasing power parity in Geary-Khamis 2005 international dollar. The data on the per capita GDP of New South Wales and Western Australia is from Genniaoli et. al. (2013, 2014). We adjust the series on per capita GDP of both states by computing the ratio of their per capita income level relative to the Australia as a whole, and use it to make their series comparable with other countries. Wherever possible, discontinuous series is composed into continuous per capita GDP series using the changes in aggregate region-level or country-level per capita GDP to approximate growth rates in the intertwining years and calculate the corresponding per capita GDP to derived a continuous series. The data on country-level per capita GDP is from Bolt and Van Zanden (2014) for the same period, 1950-2016. Together with the observations on New South Wales and Western Australia, our sample consists of 101 countries and 2 states, which totals 6,834 country/stateyear observations.

The battery of covariates used to synthetically match New South Wales and Western Australia with the rest of the world that has not undergone a similar policy shock consists of 
observable indices and variables that mimic plausibly exogenous growth and development characteristics unaffected by the e-procurement implementation itself. More specifically, the full vector of covariates comprises (i) physical geography covariates such as the size of the land area in $\mathrm{km} 2$, absolute latitude, longitude, island, desert and landlocked indicator variables from Nunn and Puga (2012), (ii) legal and institutional history covariates capturing the presence of British common law and civil law tradition (La Porta et. al. 1998), and (iii) rich past GDP per capita dynamics. The latter consists of the level of per capita GDP in the initial year (i.e. 1950), the first lag and the second lag of the per capita GDP in the period preceding the e-procurement implementation, and the growth rate of per capita GDP. Moreover, we also consider Polity2 composite indicator of democracy (Marshall et. al. 2016), and federation indicator variable (Persson and Tabellini 1998) to seek institutional similarities between New South Wales, Western Australia and the rest of the world since these are one of the few readily available institutional indices that remain unaffected by the e-procurement implementation, and yet provide an insightful comparison to capture similar institutional trends between treatment and control samples. Table 1 reports the descriptive statistics for our dataset broken down by treatment and control samples.

\section{TABLE 1 [INSERT ABOUT HERE]}

\section{$5 \quad$ Results}

\subsection{Baseline results}

Figure 1 presents the synthetic control estimated impact of e-procurement on the growth trajectories on Western Australia and New South Wales. The evidence unequivocally indicates a pervasive structural growth break emanating from the introduction of e-procurement in Western 
Australia and an almost zero impact of the procurement reform on the growth trajectory of New South Wales. After the implementation of e-procurement, Western Australia's growth trajectory departs substantially from the level implied by its country-level synthetic control group whereas no such departure is present in New South Wales after the adoption of the reform. In quantitative terms, the estimated per capita income gap between Western Australia and its synthetic control group rises immediately after the implementation of the reform. Down to the present day, the per capita income of Western Australia is 11 percent higher than the per capita income of its synthetic control group. By contrast, the growth trajectories of the New South Wales and its synthetic control group are almost identical in the years after the reform. By the last year of our sample period, the per capita income gap between the actual New South Wales and its synthetic counterpart is about 3 percent, or about one third less than the gap magnitude for Western Australia.

\section{FIGURE 1 [INSERT ABOUT HERE] \\ TABLE 2 [INSERT ABOUT HERE]}

Table 2 reports the covariate balance between the actual and synthetic versions of New South Wales and Western Australia, where a strong similarity in pre-reform covariate values is apparent in both respective cases. To further evaluate the quality of the pre-treatment fit of the model, we rely on the root mean square prediction error (RMSE). By this metric, the underlying model specification for New South Wales and Western Australia provides an excellent fit with 2.8 percent and 5.5 percent discrepancy between the real treated states and their synthetic control versions. By leveraging the RMSE against the RMSE of the benchmark model, as proposed by Adhikari and Alm (2016), our model specifications have the fit index with less than 2 percent 
pre-treatment error margin, which suggests that it is unlikely that pre-existing external and internal shocks and policy changes would affect the counterfactual dynamics of growth trajectory and the impact associated with the adoption of e-procurement. The synthetic control group for New South Wales consists of the convex combination of countries sharing similar covariate-level growth and development characteristics prior to the reform which comprises New Zealand (43\%), United States (40\%), Canada (11\%), Luxembourg (9\%), Switzerland (6\%), Hong Kong (5\%), Saudi Arabia (3\%), and Argentina (2\%). In a similar vein, the synthetic counterpart of Western Australia consists of United States (42\%), New Zealand (25\%), Luxembourg (16\%), Norway (16\%), Japan (2\%), and Ireland (1\%), respectively. Table 3 summarizes the composition of the synthetic control groups in greater detail.

\section{TABLE 3 [INSERT ABOUT HERE]}

\subsection{Testing differential trend assumption}

So far, the evidence at hand indicates relatively rigorous gains from adopting mandatory e-procurement in terms of improved economic growth trajectory in response to the reform in Western Australia. By contrast, the growth impact of the e-procurement adoption in New South Wales appears to be negligible with an undiscernible change in the growth trajectory in the subsequent period. A stark contrast in the magnitude of the per capita income gap induced by the adoption of e-procurement between Western Australia and New South Wales begets the question whether the e-procurement adoption molded a discernible and perceptible change in the trend path of economic growth.

To detect the presence or absence of the differential growth trend in response to the reform, we conduct a simple differential trend assumption test (Spruk and Kovac 2020). To 
address whether the institutional shocks produce differential trends, we test whether the growth trajectory trends of Western Australia and New South Wales differ significantly in the pre-reform versus post-reform period. Our strategy is subject to the following procedure. First, we compute the per capita income gap between Western Australia and New South Wales and their respective synthetic control groups. Second, we compute the trend slopes for both treated states in the prereform and post-reform period, and assess it against the post-procurement reform treatment indicator. And third, we test for the presence of the structural break in the trend slope induced by the e-procurement intervention, and compute the underlying Chow test statistics with the associated p-value to test the null hypothesis parametrically.

Table 4 reports the test of growth trend before and after the e-procurement policy change for New South Wales and Western Australia. As indicated in Panel A, there appears to be reasonably weak evidence of a marked and discernible change in the trend slope before and after the e-procurement adoption for the New South Wales, which reiterates further support for the notion of weak and indistinguishable reform effect. The underlying p-value of the Chow test for the presence of structural growth break is 0.125 , which implies that we fail to reject the null at conventional $5 \%$ or $10 \%$ conventional level. By contrast, Panel B reports the comparison of growth trend slopes before and after the reform for Western Australia. In a stark contrast to New South Wales, the evidence indicates a marked acceleration of the growth trend in response to the e-procurement reform. By leveraging the trend takeoff against the synthetic control group, the p-value of the Chow test statistics for the presence of the trend break induced by the reform is 0.09 and suggests that we can reject the null hypothesis of no change in the growth trend at 
$10 \%$ level. Figure 2 graphically depicts the trend comparison before and after the e-procurement adoption for both states.

\section{TABLE 4 [INSERT ABOUT HERE] \\ FIGURE 2 [INSERT ABOUT HERE]}

\subsection{In-space placebo analysis}

An important question that arises from the baseline growth effect of adopting eprocurement is whether the effects of e-procurement are specific to Western Australia and New South Wales, or is the same post-reform per capita income perceptible across other countries in the donor pool. If the latter holds, then our results are almost entirely driven by chance. How likely it is that we would obtain a similar magnitude of the per capita income gap if other countries from the donor pool were randomly chosen for the study instead of New South Wales and Western Australia? To address these issues, we iteratively apply the synthetic control estimator to countries that did not implement a large-scale e-procurement reform in the range of years during our sample period when New South Wales and Western Australia implemented it.

If the distribution of placebo effects creates per capita income gaps that are as large as the ones for the treated states, then our analysis fails to provide evidence of the significant impact of e-procurement adoption on economic growth. On the contrary, if the placebo analysis unveils a per capita income gap that is unusual for the treated states but imperceptible elsewhere, then the evidence of the significant impact of e-procurement on growth becomes plausible. Our placebo analysis follows the established procedure (Abadie et. al. 2010) by shifting the treated states into the donor pool and reassigning the intervention to each country in the donor pool. This allows us to proceed as if one of the countries implemented a large-scale procurement reform at the same footing as Western Australia and New South Wales. This procedure yields the 
corresponding distribution of the per capita income gaps allowing for inference and statistical significance of the growth effects to be drawn upfront. Notice that our key interest in the placebo analysis lies in Western Australia given a relatively large positive per capita income gap induced by the adoption of e-procurement, and slightly less in New South Wales given an almost nonexistent post-reform per capita income gap between the state and its country-level synthetic control group.

Figure 3 provides a balance of the per capita income dynamics in New South Wales and Western Australia before and after the reform, and the countries in the donor pool. A startling comparison of per capita income trajectories in pre- vs. post-reform period indicates a somewhat marked slowdown in the growth trajectory of New South Wales after the reform and an accelerated improvement in the growth trajectory of Western Australia. After the e-procurement adoption, the trend balance implies that New South Wales fell out of the $90^{\text {th }}$ percentile of our sample world income distribution whereas Western Australia entered the $90^{\text {th }}$ percentile of the distribution after the adoption of e-procurement, which indicates a marked shift in the relative level of per capita income induced by the e-procurement intervention.

Figure 4 displays the key result of the in-space placebo test. The gray lines represent the per capita income gap associated with each of the 101 country-level runs of the placebo test. The line itself represents the per capita income difference between each country in the donor pool and its synthetic control group. The black line denotes the original per capita income gap estimated for New South Wales and Western Australia. The evidence clearly suggests that the estimated per capita income gap appears to be unusual and moderately large for Western Australia but not for New South Wales relative to the distribution of the gaps for the full set of countries in the donor pool. The synthetic matching of both states on observable covariates prior to the e- 
procurement adoption provides an excellent fit for per capita income, which renders the lack of fit attributable to the estimated gap very unlikely. Given a relatively large and unusual gap for Western Australia in the post-reform period, and the absence of such gap in New South Wales, the placebo analysis provides the necessary evidence to substantiate the claim of a significant eprocurement adoption impact on growth in Western Australia but not in New South Wales given the continuance of the almost zero per capita income gap in the post-reform period. To further address the relative rarity of obtaining extreme placebo estimates, we discard the placebo gaps where the pre-reform RMSE is four times (i.e. Panel A) and five times (i.e. Panel B) greater than that of the treated states.

\section{FIGURE 4 [INSERT HERE]}

Figure 5 reports the computed probabilities that the estimated per capita income gap attributed to the e-procurement policy intervention is zero, thus being observed by chance alone. The p-values are obtained through a permutation test when the e-procurement intervention is reassigned to all 101 countries in the donor pool, and can be interpreted as the proportion of countries having a similar post-reform gap to the ones estimated for New South Wales and Western Australia. Although incomplete, such randomization inference allows us to determine whether the estimated per capita income gaps differ significantly between the treated states and the donor pool where a similar intervention is not perceptible. The evidence readily advocates high p-values associated with the per capita income gap for New South Wales. This implies that the adoption of e-procurement reform cannot be linked to higher per capita income in the postreform period since the quasi p-value moves from around 0.4 in the first post-reform year to almost 0.9 in the ultimate post-intervention year. By contrast, the p-values for Western Australia 
are consistently low and in the range between 0.01 and 0.10 in the thirteen years after the adoption of e-procurement. This implies that there is generally less than 10 percent chance that if other countries are picked at random for the study instead of Western Australia, that we would obtain the per capita income gap of similar magnitude under a random permutation of the eprocurement treatment. By and large, the evidence confirms the unique and growth-friendly effect of the e-procurement adoption on Western Australian growth trajectory whereas we fail to find the effect of similar size and significance in New South Wales, respectively.

\section{FIGURE 5 [INSERT ABOUT HERE]}

\subsection{Falsely assigned policy year}

To further evaluate the credibility of the baseline growth effect of e-procurement, we conduct another placebo study by falsely assigning the year of the policy intervention for both treated states. We rely on the prior work of Abadie et. al. (2015) studying the effect of German unification (i.e. Wiedervereinigung) on the growth trajectory of West German economy. To determine whether the counterfactual growth dynamics is driven by unification itself, the authors reassign the year of unification from the actual year (i.e. 1990) to the middle of the pre-unification period (i.e. 1975), and use out-of-sample validation technique to compute the synthetic control group for West Germany. They show that when the unification year is moved to the false date in the middle of pre-treatment period, the per capita income gap between West Germany and its synthetic control group disappears, and this support the argument of the unique growth effect of unification. We adopt this approach, and reassign the year of e-procurement from the actual dates to the year 1990 as the rough middle range of the pre-intervention period, and apply the synthetic control estimator to New South Wales and Western Australia. 
Figure 6 presents the synthetic control estimate of the growth impact of e-procurement using falsely assigned year of the intervention alongside the randomization-based p-values associated with our in-time placebo analysis. The evidence confirms our prior estimates. In particular, the growth trajectory of New South Wales appears to be unchanged in response to the adoption of e-procurement with the pattern of almost zero per capita income gap. By contrast, the growth trajectory of Western Australia tends to be unchanged by the e-procurement placebo intervention in 1990. Using the 1990 as a quasi-treatment year, the evidence uncovers that the per capita income gap between Western Australia and its synthetic counterparts begins to unfold precisely around the year of 2000 when the e-procurement was implemented. This pattern is further reinforced by the distribution of p-values on the placebo effect. In specific terms, the pvalues associated with the placebo intervention for New South Wales are very similar to the baseline analysis. By contrast, the p-values for the same placebo intervention for Western Australia indicate very high p-values for the period 1990-2000 and a rapid drop afterwards which coincides with the precise timing of the reform. This clearly suggests that the gap from Figure 1 reflects the impact of the e-procurement rather than a potential absence or lack of predictive power of our synthetic control specification since the 1990 placebo intervention has no discernible effect on the trajectory of Western Australia's economic growth.

\section{FIGURE 6 [INSERT ABOUT HERE]}

\subsection{Leave-one-out analysis}

The size of the growth effect of e-procurement depends on the composition of the synthetic control group and the covariate-level characteristics that describe it. For both treated states, the composition of synthetic control group is dominated by the United States and New Zealand. In 
the synthetic New South Wales, the country-level weights for New Zealand and United States are 0.43 and 0.39 , respectively, which implies that they together account for more than 80 percent of the total per capita income variance of the synthetic control group. In a similar vein, the New Zealand and United States account for about 66 percent of the per capita income variance of Western Australia's synthetic control group. To address the sensitivity of the baseline growth effect with respect to the country-level weight sets, we follow Klößner et. al. (2019), and iteratively re-estimate the baseline model specification by omitting New Zealand and United States in each iteration of the estimated specification, which allows to evaluate to what extent is the baseline growth effect driven by the two particular countries from the donor pool.

Table 5 reports the composition of alternative synthetic control groups for Western Australia and New South Wales without the New Zealand and United States. Our most rigorous robustness check is the third iteration block when both control countries are simultaneously excluded from the donor pool. The evidence suggests that without them, the growth trajectory of New South Wales prior to the e-procurement reform is best reproduced as a convex combination of growth trajectories of Canada (59\%), Argentina (23\%), and Luxembourg (19\%) with a very similar size of the pre-intervention RMSE (=0.107). Without the New Zealand and United States, the growth trajectory of Western Australia prior to the e-procurement take-up is best reproduced as a convex combination of trajectories of Canada (64\%), Luxembourg (30\%), Norway $(5 \%)$, and Malaysia $(<1 \%)$ with no loss of goodness of fit given a very low preintervention RMSE (=0.049). Figure 7 depicts the growth effect of e-procurement by leaving the United States and New Zealand out of the donor pool. Notice that the underlying growth effect remains basically unchanged. The structural break in the per capita income trajectory of real 
Western Australia is triggered by the e-procurement adoption in 2000 even which rules out the lack of goodness of fit as a potential driver of results.

TABLE 5 [INSERT ABOUT HERE]

FIGURE 7 [INSERT ABOUT HERE]

\subsection{Effect with shorter pre-treatment period}

The evidence so far indicates relatively rigorous growth gains of e-procurement for Western Australia and almost zero effect of e-procurement reform in New South Wales. The underlying per capita income gap is based on a reasonably long pre-intervention period that starts in 1950 and ends around the year of 2000. This begets a question whether the estimated per capita income is attributed to the relatively long pre-treatment period, which might invoke pre-reform shocks and policy changes as a potential source of counterfactual growth dynamics. To partially address this question, we narrow the pre-treatment period to the years 1990 to 2000 (i.e. 2001 for New South Wales), and re-estimate the baseline growth trajectory specification, and further evaluate the credibility of our results.

Figure 8 presents the growth impact of e-procurement on a narrower pre-treatment period that begins in 1990. The baseline growth effects appear to be very similar to the original estimates in Figure 1, even when the pre-intervention period is shortened substantially. In particular, the positive per capita income gap induced by the e-procurement intervention in Western Australia, and a zero gap in New South Wales are evident with similarly low p-values of the treatment effect for the former, and high p-values for the latter. In particular, the estimated gap for Western Australia is 6 percent with pre-intervention $\mathrm{RMSE}=0.042$ whereas the negative 8 percent gap for New South Wales does not appear to be perceivable by the adoption of e-procurement unlike the gap for Western Australia. Table 6 reports the composition of synthetic control groups on a 
shorter pre-treatment period. On a narrower pre-intervention period, the synthetic New South Wales's growth trajectory is best reproduced by a convex combination of New Zealand (51\%), United States (36\%), Norway (10\%), and Saudi Arabia (4\%). The synthetic counterpart of Western Australia prior to the e-procurement consists of the growth and development characteristics of United States (42\%), Luxembourg (31\%), Saudi Arabia (12\%), New Zealand (8\%), and Hong Kong (8\%), which appears to be similar to the original composition in Table 2 and leave-one-out composition in Table 5.

FIGURE 8 [INSERT ABOUT HERE] TABLE 6 [INSERT ABOUT HERE]

\subsection{Region-level analysis}

Our analysis so far has assessed the economic growth trajectories of New South Wales and Western Australia against the rest of the world using other countries that did not undergo such type of e-procurement reform as a control sample. One caveat arising from our results is that such comparison is condones the common law jurisdiction, to which both treated states belong, with the civil-law jurisdiction where the policy implementation, design and enforcement differences are too apparent to warrant a meaningful comparison. To address this issue, we construct a control sample that consists of subnational units in common-law jurisdictions similar to Australia. By relying on the Genniaoli et. al. (2014) subnational per capita GDP estimates, we construct a sample that consists of US states, Canadian provinces and regions in the United Kingdom to construct the respective synthetic control groups for Western Australia and New South Wales. Apart from the historical narratives that arise from the adoption of the English common law and similar colonial history, such comparison can potentially unravel the growth 
differences emanating from the adoption of e-procurement expected in the common-law jurisdiction.

Figure 9 depicts the economic growth effect of e-procurement using regions in the common-law jurisdiction as a donor pool. The evidence strikingly confirms the baseline growth effect. In particular, the growth trajectory of New South Wales remains unchanged by the adoption of e-procurement in 2002 whereas the growth trajectory of Western Australia departs substantially from its synthetic control group with a relatively large and positive per capita income gap. Assessed against other regions, the per capita income of Western Australia in the last year of the post-intervention period appears to be 18 percent higher compared to the common-law regions with a similar pre-intervention growth dynamics. On the other hand, the per capita income difference between the real New South Wales and its synthetic counterpart is $2 \%$ but appears to be unrelated to the 2002 adoption of e-procurement. At the regional level, the growth trajectory of New South Wales prior to the e-procurement reform can be best reproduced by a combination of covariate-level characteristics of Florida (69\%), Wales (23\%), East Anglia (6\%), and Michigan (2\%). The states and regions in common-law jurisdiction that best reproduced Western Australia's growth path prior to the implementation of e-procurement reform consist of Nevada (35\%), Georgia (19\%), South East England with London (17\%), Florida (15\%), and Washington D.C. (14\%), respectively. The size of RMSE is very small for both treated states, and is 0.032 and 0.044 , which implies that it is unlikely that the per capita income gap in the post-treatment period would be attributed to the lack of fit in the pre-treatment period. Table 7 reports the composition of region-level synthetic control groups.

FIGURE 9 [INSERT ABOUT HERE]

TABLE 7 [INSERT ABOUT HERE] 
Figure 10 reports the inverted percentile rank of p-values associated with the treatment effect of e-procurement on growth of Western Australia and shows that there appears to be substantial evidence in support of the structural break in the distribution of p-values induced by the e-procurement policy intervention in 2000. In particular, we assess the level of p-values against the interaction term between the time trend and the post-2000 indicator variable. The underlying coefficient on Dube and Zipperer (2015) percentile rank is 0.005 with the $95 \%$ confidence bounds at 0.001 and 0.009 , and with the p-value $=0.009$, which implies that the structural break coefficient is statistically significant at $1 \%$, respectively. The p-values associated with the growth effect of e-procurement are consistently below the $10 \%$ significance threshold for the most part in the post-treatment period, and confirm a rigorous and relatively large effect of e-procurement on growth for such a short post-intervention period.

\section{FIGURE 10 [INSERT HERE]}

\subsection{Confounding effect of the mining boom}

Our final robustness check concerns whether the estimated impact of e-procurement on growth is confounded with the mining boom that has affected the economy of Western Australia around the year 2003. Our rationale is that if we find the evidence of similar structural break in the year of the mining boom, then our interpretation is that the analysis fails to provide the evidence of significant and identifiable effect of e-procurement precisely because the latter would be confounded by the mining boom. By contrast, if we find the evidence distinctive from the one we uncover with the adoption of e-procurement, then our interpretation is that the analysis so far provides evidence of substantial and significant effect of e-procurement on growth. To address 
this caveat, we reassign the year of the intervention from 2000 to 2003, and apply the synthetic control estimator to compare the per capita income gap across both specifications.

Figure 11 compares the growth effects of e-procurement and mining boom together with the comparison of p-values arising from both types of effects. The evidence suggests that the adoption of e-procurement has triggered a gap between Western Australia and its synthetic control group that is both perceivable and immediate. By contrast, we find no effect of the mining boom on the per capita income gap between Western Australia and its synthetic counterpart. In particular, when the treatment year is shifted to the first year of the mining boom, the evidence unequivocally suggests that the break in the per capita income gap is perceivable precisely in the year of e-procurement adoption, and not in the year when mining boom began. This is further reinforced by the comparison of p-values for both shocks. In particular, with each year that lapses from the beginning of the mining boom, the p-values seem to rise substantially. By the last year of the post-treatment period, the p-value associated with the mining boom rises above 0.5 , which further implies that the mining boom is unlikely to confound the growth effect of e-procurement.

\section{FIGURE 11 [INSERT HERE]}

\section{Conclusion}

The notion that e-procurement matters for a wide range of economic and policy outcomes has acclaimed substantial scholarly attention. The notion whether the adoption of electronic procurement matters for economic growth has received little empirical attention. In this paper, we examine the contribution of adopting e-procurement to economic growth. To this end, we 
exploit the implementation of large-scale mandatory e-procurement platform in Western Australia in 2000 and New South Wales 2002.

By matching the economic growth trajectory and its covariates of both states with the rest of the world, we provide a plausibly exogenous source of variation to determine how much of the change in economic growth is attributed to the implementation of e-procurement. Using a large donor pool of more than 100 countries, we find mixed evidence of the economic growth impact of e-procurement. We find that the institutional and policy details behind the implementation of e-procurement matter a great deal in whether the reform translates into the shift in economic growth. In particular, we find that the economic growth trajectory of New South Wales remains unchanged in response to the adoption of e-procurement. The finding appears to be consistent with the audit reports emphasizing significant irregularities in the local councils, lack of regulatory oversight and numerous opportunities for corruption that failed to translate into a discernible and perceivable beneficial growth impact. By contrast, we find evidence of significant improvement in the path of economic growth in response to the implementation of e-procurement in Western Australia. In comparison with New South Wales, e-procurement reform has been hailed by several scholars as an example of transparent and accountable reform with low ex-ante and ex-post transaction costs.

In quantitative terms, we find that per capita income of Western Australia in response to the adoption of mandatory e-procurement is 8 percent higher than implied by the counterfactual scenario of no-reform. The estimated growth impact of mandatory e-procurement adoption is robust to the composition of synthetic control groups, and does not seem to be confounded by pre-existing policy changes or the mining boom in the adjacent years, and appears 
even stronger when Western Australia is matched against the subnational states, provinces and regions in similar common-law jurisdictions such as United States, Canada and England.

\section{References}

Abadie, A., \& Gardeazabal, J. (2003). The economic costs of conflict: A case study of the Basque Country. American Economic Review 93(1), 113-132.

Abadie, A., Diamond, A., \& Hainmueller, J. (2010). Synthetic control methods for comparative case studies: Estimating the effect of California's tobacco control program. Journal of the American Statistical Association, 105(490), 493-505.

Abadie, A., Diamond, A., \& Hainmueller, J. (2015). Comparative politics and the synthetic control method. American Journal of Political Science 59(2), 495-510.

Acemoglu, D., Johnson, S., \& Robinson, J. A. (2005). Institutions as a fundamental cause of long-run growth. Handbook of Economic Growth, 1, 385-472.

Adhikari, B., \& Alm, J. (2016). Evaluating the economic effects of flat tax reforms using synthetic control methods. Southern Economic Journal 83(2), 437-463.

Afonso, A., Schuknecht, L., \& Tanzi, V. (2010). Public sector efficiency: evidence for new EU member states and emerging markets. Applied Economics 42(17), 2147-2164.

Alesina, A., \& Perotti, R. (1994). The political economy of growth: a critical survey of the recent literature. The World Bank Economic Review 8(3), 351-371.

Alesina, A., Özler, S., Roubini, N., \& Swagel, P. (1996). Political instability and economic growth. Journal of Economic Growth 1(2), 189-211.

Angelopoulos, K., Philippopoulos, A., \& Tsionas, E. (2008). Does public sector efficiency matter? Revisiting the relation between fiscal size and economic growth in a world sample. Public Choice 137(1-2), 245-278.

Arruñada, B., \& Garoupa, N. (2005). The choice of titling system in land. The Journal of Law and Economics 48(2), 709-727.

Audit Office of New South Wales. 2011. New South Wales Auditor-General's Report:

Volume One 2011. Sydney: The Audit Office, Government of New South Wales.

Ben-Michael, E., Feller, A., \& Rothstein, J. (2018). The augmented synthetic control method. Working Paper No. 1811.04170, arXiv.

Berkowitz, D., Pistor, K., \& Richard, J. F. (2003). Economic development, legality, and the transplant effect. European Economic Review 47(1), 165-195.

Byrne, A. 2013. Government procurement in Western Australia: beyond compliance. Keeping Good Companies 65(7), 394-399.

Bolt, J., \& Van Zanden, J. L. (2014). The M addison P roject: collaborative research on historical national accounts. The Economic History Review 67(3), 627-651.

Botosaru, I., \& Ferman, B. (2019). On the role of covariates in the synthetic control method. The Econometrics Journal 22(2), 117-130.

Campos, N. F., Karanasos, M. G., \& Tan, B. (2012). Two to tangle: Financial development, political instability and economic growth in Argentina. Journal of Banking \& Finance 36(1), 290-304. 
Castro, R., Clementi, G. L., \& MacDonald, G. (2009). Legal institutions, sectoral heterogeneity, and economic development. The Review of Economic Studies 76(2), 529-561.

Callender, G. \& Schapper, P. 2007. "Public Procurement Reform in Western Australia: A federal-state evaluation", in Public Procurement: International Cases and Commentary, ed. Knight, L., Ch.3 pp.25-41. London: Routledge.

Coatsworth, J. H. (2008). Inequality, institutions and economic growth in Latin America. Journal of Latin American Studies 40(3), 545-569.

Commonwealth of Australia (COA). 1994. Australian Government Purchasing Policies, 'Buying Our Future'. Canberra: Australian Government Publishing Service.

Cooter, R. \& H.B. Schaefer (2012). The Solomon's Knot: How Law Can End the Poverty of Nations? Princeton, NJ: Princeton University Press.

de la Escosura, L. P., \& Sanz-Villarroya, I. (2009). Contract enforcement, capital accumulation, and Argentina's long-run decline. Cliometrica 3(1), 1-26.

De Haan, J., Lundström, S., \& Sturm, J. E. (2006). Market-oriented institutions and policies and economic growth: A critical survey. Journal of Economic Surveys 20(2), 157-191.

Department of Public Works and Services (DPWS). 2002. Electronic Procurement Implementation Strategy - Guidelines. Sydney: Department of Public Works and Services, Government of New South Wales.

Department of Treasury and Finance (DTF). 2008. Procurement Reforms 2003-2008: Program Review. Perth: Department of Treasury and Finance, Government of Western Australia.

Dube, A. \& B. Zipperer (2015). Pooling multiple case studies using synthetic controls: an application to minimum wage policies. Discussion Paper No. 8944, Institute for the Study of Labor.

Easterly, W., \& Levine, R. (2003). Tropics, germs, and crops: how endowments influence economic development. Journal of Monetary Economics 50(1), 3-39.

Easterly, W., \& Levine, R. (2016). The European origins of economic development. Journal of Economic Growth 21(3), 225-257.

Fatás, A., \& Mihov, I. (2013). Policy volatility, institutions, and economic growth. Review of Economics and Statistics 95(2), 362-376.

Gennaioli, N., La Porta, R., Lopez-de-Silanes, F., \& Shleifer, A. (2013). Human capital and regional development. The Quarterly Journal of Economics, 128(1), 105-164.

Gennaioli, N., La Porta, R., De Silanes, F. L., \& Shleifer, A. (2014). Growth in regions. Journal of Economic Growth, 19(3), 259-309.

Gorodnichenko, Y., \& Roland, G. (2017). Culture, institutions, and the wealth of nations. Review of Economics and Statistics 99(3), 402-416.

Hall, R. E., \& Jones, C. I. (1999). Why do some countries produce so much more output per worker than others? The Quarterly Journal of Economics 114(1), 83-116.

Independent Commission Against Corruption (ICAC). 2011. Corruption Risks in NSW Government Procurement: The Management Challenge. Sydney: Independent Commission Against Corruption, Government of New South Wales.

Ippoliti, R., Melcarne, A., \& Ramello, G. B. (2015). The Impact of judicial efficiency on entrepreneurial action: A european perspective. Economic Notes: Review of Banking, Finance and Monetary Economics 44(1), 57-74. 
Klößner, S., Kaul, A., Pfeifer, G., \& Schieler, M. (2018). Comparative politics and the synthetic control method revisited: A note on Abadie et al.(2015). Swiss Journal of Economics and Statistics 154(1), 1-11.

Knack, S., \& Keefer, P. (1995). Institutions and economic performance: cross-country tests using alternative institutional measures. Economics \& Politics 7(3), 207-227.

La Porta, R., Lopez-de-Silanes, F., Shleifer, A., \& Vishny, R. W. (1998). Law and finance. Journal of Political Economy, 106(6), 1113-1155.

Levine, R. (1998). The legal environment, banks, and long-run economic growth. Journal of Money, Credit and Banking, 596-613.

Marciano, A., Melcarne, A., \& Ramello, G. B. (2019). The economic importance of judicial institutions, their performance and the proper way to measure them. Journal of Institutional Economics 15(1), 81-98.

Marshall, M., Jagger, K. \& Gurr, T. (2016): Polity IV project: political regime characteristics and transitions, 1800-2017. Vienna, VA: Center for Systemic Peace.

Mauro, P. (1995). Corruption and growth. The Quarterly Journal of Economics 110(3), 681-712.

Méon, P. G., \& Sekkat, K. (2005). Does corruption grease or sand the wheels of growth?. Public Choice 122(1-2), 69-97.

New South Wales Treasury. 2004. Procurement Planning Program 2003-04 Report (TRP 04-3). Sydney: Treasury, Government of New South Wales.

North, D. C. (1987). Institutions, transaction costs and economic growth. Economic Inquiry 25(3), 419-428.

Nunn, N., \& Puga, D. (2012). Ruggedness: The blessing of bad geography in Africa. Review of Economics and Statistics 94(1), 20-36.

Olson, M. (1992). Do lawyers impair economic growth. Law \& Social Inquiry 17, 625-630.

Parente, S. L., \& Prescott, E. C. (2002). Barriers to Riches. Cambridge, MA: MIT Press.

Persson, T., \& Tabellini, G. (1999). Political economics and macroeconomic policy. In: K. Arrow \& M.D. Intriligator (eds), Handbook of Macroeconomics, 1(C): 1397-1482.

Posner, R. A. (1998). Creating a legal framework for economic development. The World Bank Research Observer 13(1), 1-11.

Przeworski, A., Bardhan, P. K., Kolarska-Bobińska, L., Pereira, L. C. B., Wiatr, J. J., \& Bruszt, L. (1995). Sustainable Democracy. Cambridge University Press.

Rajan, R. G., \& Zingales, L. (2001). Financial systems, industrial structure, and growth. Oxford Review of Economic Policy, 17(4), 467-482.

Rodrik, D. (2000). Institutions for high-quality growth: what they are and how to acquire them. Studies in Comparative International Development 35(3), 3-31.

Roland, G. (2004). Understanding institutional change: Fast-moving and slow-moving institutions. Studies in Comparative International Development 38(4), 109-131.

Rubin, D. B. (1974). Estimating causal effects of treatments in randomized and nonrandomized studies. Journal of Educational Psychology 66(5), 688-701.

Scully, G. W. (1988). The institutional framework and economic development. Journal of Political Economy 96(3), 652-662.

Smith, A. (1776). An Inquiry into the Nature and Causes of the Wealth of Nations. New York, NY: Modern Library. 
Spruk, R. \& Kovac, M. (2020). Does a ban on trans-fats improve public health: synthetic control evidence from Denmark. Forthcoming: Swiss Journal of Economics and Statistics.

Torstensson, J. (1994). Property rights and economic growth: an empirical study. Kyklos 47(2), 231-247.

Williamson, J. (1994). The Political Economy of Policy Reform. Washington DC: Peterson Institute. 
Table 1: Descriptive Statistics

\begin{tabular}{rcc|cc}
\hline \hline & $\begin{array}{c}\text { New South } \\
\text { Wales }\end{array}$ & $\begin{array}{c}\text { Rest of the } \\
\text { World }\end{array}$ & $\begin{array}{c}\text { Western } \\
\text { Australia }\end{array}$ & $\begin{array}{c}\text { Rest of the } \\
\text { World }\end{array}$ \\
\hline Panel A: Dependent Variable & \multicolumn{3}{c}{} \\
\hline GDP per capita & 25,795 & 10,952 & 27,173 & 10,952 \\
\hline Panel B: Observable Synthetic Matching Covariates & 3,591 & 12,708 & 3,591 \\
\hline GDP per capita in 1950 & 12,429 & 6,374 & 27,173 & 6,374 \\
\hline GDP per capita(t-1) & 23,860 & 6,438 & 26,903 & 6,438 \\
\hline GDP per capita(t-2) & 23,623 & 0.026 & 0.004 & 0.026 \\
\hline Growth of GDP per capita & 0.022 & 31.48 & 26.67 & 31.48 \\
\hline Absolute latitude & 31.25 & 12.43 & 121.62 & 12.43 \\
\hline Longitude & 146.92 & 0.12 & 1 & 0.12 \\
\hline Island & 1 & 0.19 & 0 & 0.19 \\
\hline Landlocked & 0 & 915,273 & $2,646,000$ & 915,273 \\
\hline Land area & 809,404 & 40,690 & 1,432 & 40,690 \\
\hline Population Size & 5,399 & 167,92 & 0,5 & 167,92 \\
\hline Population Density & 2,01 & 0.015 & 0.004 & 0.015 \\
\hline Population Growth & 0.013 & 0.23 & 1 & 0.23 \\
\hline British Common Law & 1 & 9.78 & 10 & 9.78 \\
\hline Polity2 & 10 & 0.19 & 1 & 0.19 \\
\hline
\end{tabular}


Figure 1: Economic Growth Impact of E-Procurement

(a) New South Wales

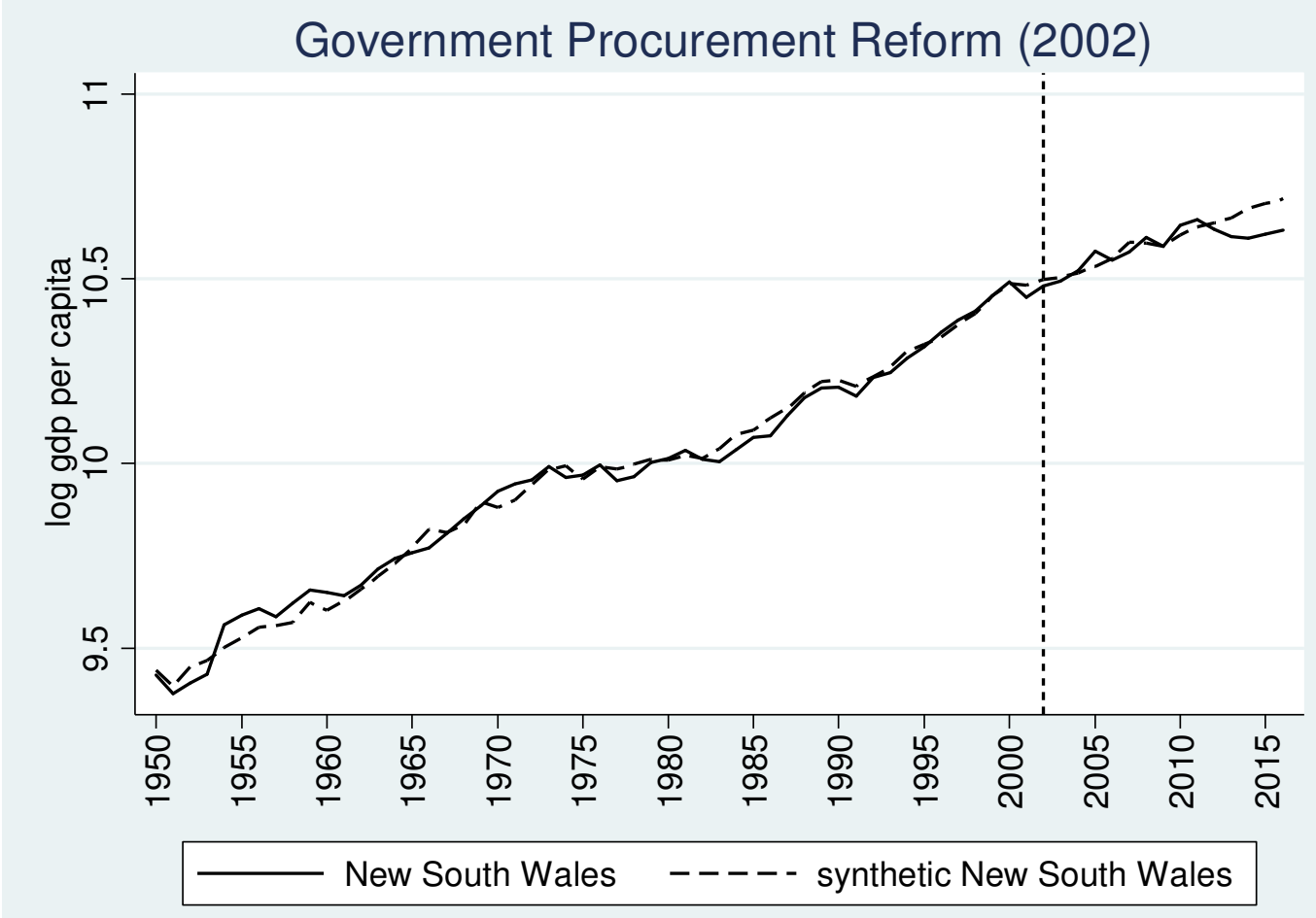

(b) Western Australia

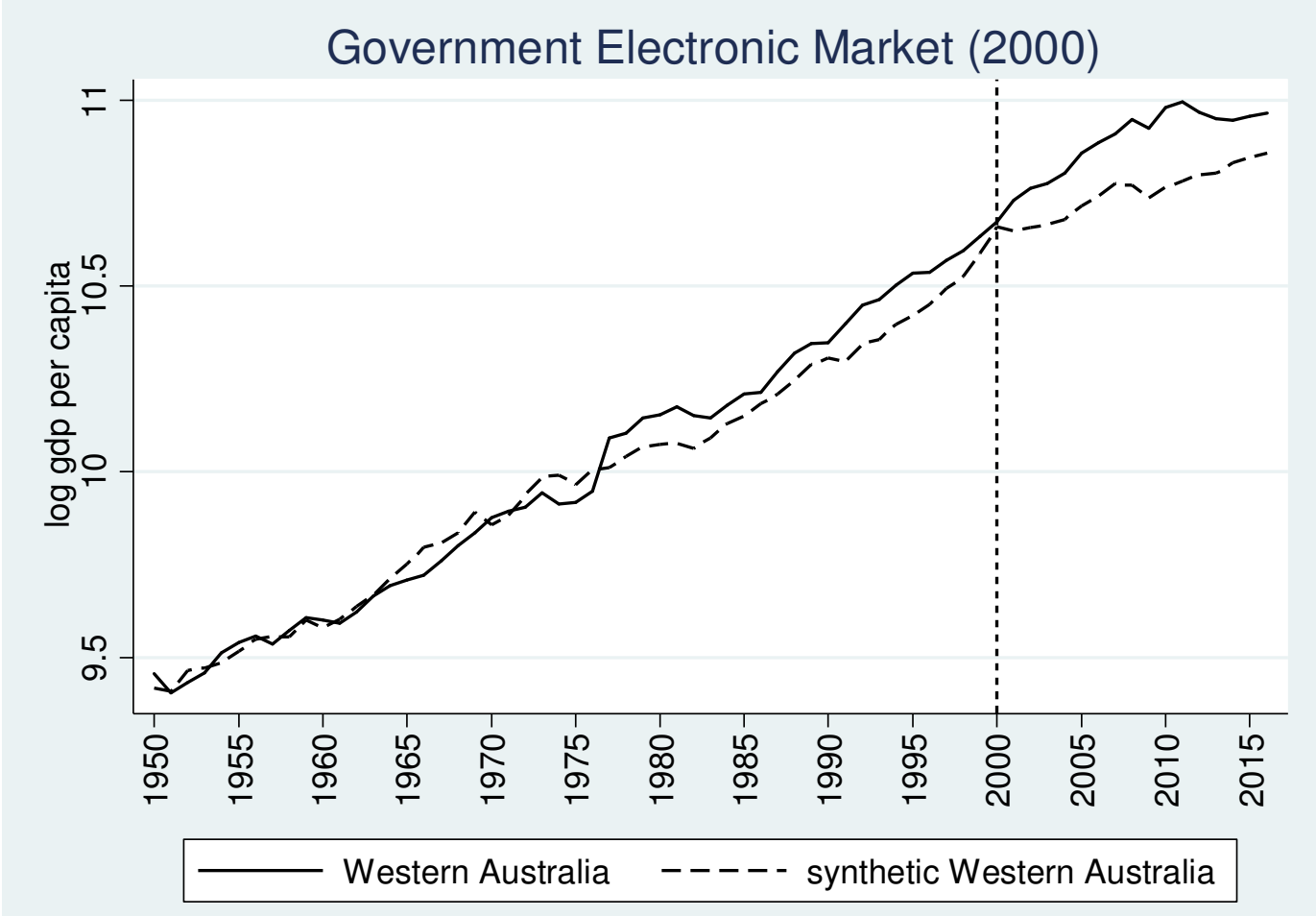


Table 2: Covariate Balance

\begin{tabular}{|c|c|c|c|c|}
\hline & \multicolumn{2}{|c|}{ New South Wales } & \multicolumn{2}{|c|}{ Western Australia } \\
\hline & Actual & Synthetic & Actual & Synthetic \\
\hline \multicolumn{5}{|c|}{ Panel A: Observable Synthetic Matching Covariates } \\
\hline Log GDP per capita in 1950 & 9.42 & 9.43 & 9.45 & 9.41 \\
\hline Log GDP per capita(t-1) & 9.93 & 9.93 & 10.15 & 10.15 \\
\hline Log GDP per capita(t-2) & 9.92 & 9.92 & 10.17 & 10.14 \\
\hline Log GDP per capita $\left(\mathrm{T}_{0}-1\right)$ & 10.44 & 10.48 & 10.64 & 10.58 \\
\hline Growth of GDP per capita & 1.002 & 1.002 & 0.974 & 0.980 \\
\hline Absolute latitude & 31.25 & 43.84 & 26.67 & 48.40 \\
\hline Longitude & 146.92 & 31.01 & 121.62 & -1.51 \\
\hline Island & 1 & 0.400 & 1 & 0.43 \\
\hline Landlocked & 0 & 0.058 & 0 & 0 \\
\hline Log Land area & 13.60 & 13.44 & 14.78 & 13.21 \\
\hline Log Population Size & 8.47 & 9.57 & 6.99 & 9.46 \\
\hline Log Population Density & 0.006 & 0.033 & 0.0004 & 0.035 \\
\hline Population Growth & 1.001 & 1.001 & 0.972 & 0.990 \\
\hline British Common Law & 1 & 0.856 & 1 & 0.679 \\
\hline Polity2 & 10 & 9.44 & 10 & 9.98 \\
\hline Federation & 1 & 0.398 & 1 & 0.419 \\
\hline
\end{tabular}


Table 3: Composition of Synthetic Control Groups

\begin{tabular}{|c|c|c|}
\hline & New South Wales (2002) & Western Australia (2000) \\
\hline Root MSPE & 0.028 & 0.055 \\
\hline Albania & 0 & 0 \\
\hline Argentina & 0.023 & 0 \\
\hline Austria & 0 & 0 \\
\hline Bangladesh & 0 & 0 \\
\hline Belgium & 0 & 0 \\
\hline Bolivia & 0 & 0 \\
\hline Bosnia and Herzegovina & 0 & 0 \\
\hline Botswana & 0 & 0 \\
\hline Brazil & 0 & 0 \\
\hline Bulgaria & 0 & 0 \\
\hline Cameroon & 0 & 0 \\
\hline Canada & 0.107 & 0 \\
\hline Cape Verde & 0 & 0 \\
\hline Chile & 0 & 0 \\
\hline China & 0 & 0 \\
\hline Colombia & 0 & 0 \\
\hline Costa Rica & 0 & 0 \\
\hline Cote d'Ivoire & 0 & 0 \\
\hline Croatia & 0 & 0 \\
\hline Cyprus & 0 & 0 \\
\hline Czech Republic & 0 & 0 \\
\hline Denmark & 0 & 0 \\
\hline Dominican Republic & 0 & 0 \\
\hline Ecuador & 0 & 0 \\
\hline Egypt & 0 & 0 \\
\hline El Salvador & 0 & 0 \\
\hline Estonia & 0 & 0 \\
\hline Finland & 0 & 0 \\
\hline France & 0 & 0 \\
\hline Germany & 0 & 0 \\
\hline Ghana & 0 & 0 \\
\hline Greece & 0 & 0 \\
\hline Guatemala & 0 & 0 \\
\hline Honduras & 0 & 0 \\
\hline Hong Kong & 0.049 & 0 \\
\hline Hungary & 0 & 0 \\
\hline Iceland & 0 & 0 \\
\hline India & 0 & 0 \\
\hline Indonesia & 0 & 0 \\
\hline Iran & 0 & 0 \\
\hline Iraq & 0 & 0 \\
\hline Ireland & 0 & 0.011 \\
\hline Israel & 0 & 0 \\
\hline Italy & 0 & 0 \\
\hline Japan & 0 & 0.019 \\
\hline Jordan & 0 & 0 \\
\hline
\end{tabular}




\begin{tabular}{|c|c|c|}
\hline Kosovo & 0 & 0 \\
\hline Lebanon & 0 & 0 \\
\hline Luxembourg & 0.086 & 0.162 \\
\hline Macedonia & 0 & 0 \\
\hline Madagascar & 0 & 0 \\
\hline Malaysia & 0 & 0 \\
\hline Malta & 0 & 0 \\
\hline Mauritius & 0 & 0 \\
\hline Mexico & 0 & 0 \\
\hline Mongolia & 0 & 0 \\
\hline Montenegro & 0 & 0 \\
\hline Morocco & 0 & 0 \\
\hline Mozambique & 0 & 0 \\
\hline Namibia & 0 & 0 \\
\hline Nepal & 0 & 0 \\
\hline New Zealand & 0.430 & 0.249 \\
\hline Nicaragua & 0 & 0 \\
\hline Nigeria & 0 & 0 \\
\hline Norway & 0 & 0.158 \\
\hline Oman & 0 & 0 \\
\hline Panama & 0 & 0 \\
\hline Paraguay & 0 & 0 \\
\hline Peru & 0 & 0 \\
\hline Philippines & 0 & 0 \\
\hline Poland & 0 & 0 \\
\hline Portugal & 0 & 0 \\
\hline Puerto Rico & 0 & 0 \\
\hline Romania & 0 & 0 \\
\hline Russia & 0 & 0 \\
\hline Rwanda & 0 & 0 \\
\hline Saudi Arabia & 0.028 & 0 \\
\hline Senegal & 0 & 0 \\
\hline Serbia & 0 & 0 \\
\hline Singapore & 0 & 0 \\
\hline Slovakia & 0 & 0 \\
\hline Slovenia & 0 & 0 \\
\hline South Africa & 0 & 0 \\
\hline South Korea & 0 & 0 \\
\hline Spain & 0 & 0 \\
\hline Sweden & 0 & 0 \\
\hline Switzerland & 0.058 & 0 \\
\hline Syria & 0 & 0 \\
\hline Thailand & 0 & 0 \\
\hline e Netherlands & 0 & 0 \\
\hline o and Tobago & 0 & 0 \\
\hline Tunisia & 0 & 0 \\
\hline Turkey & 0 & 0 \\
\hline Ukraine & 0 & 0 \\
\hline ited Kingdom & 0 & 0 \\
\hline
\end{tabular}




\begin{tabular}{rc|c} 
United States & 0.398 & 0.419 \\
Uruguay & 0 & 0 \\
Venezuela & 0 & 0 \\
Vietnam & 0 & 0 \\
Zambia & 0 & 0 \\
Zimbabwe & 0 & 0 \\
\hline
\end{tabular}


Table 4: Comparison of Growth Trends Before and After Procurement Policy Change

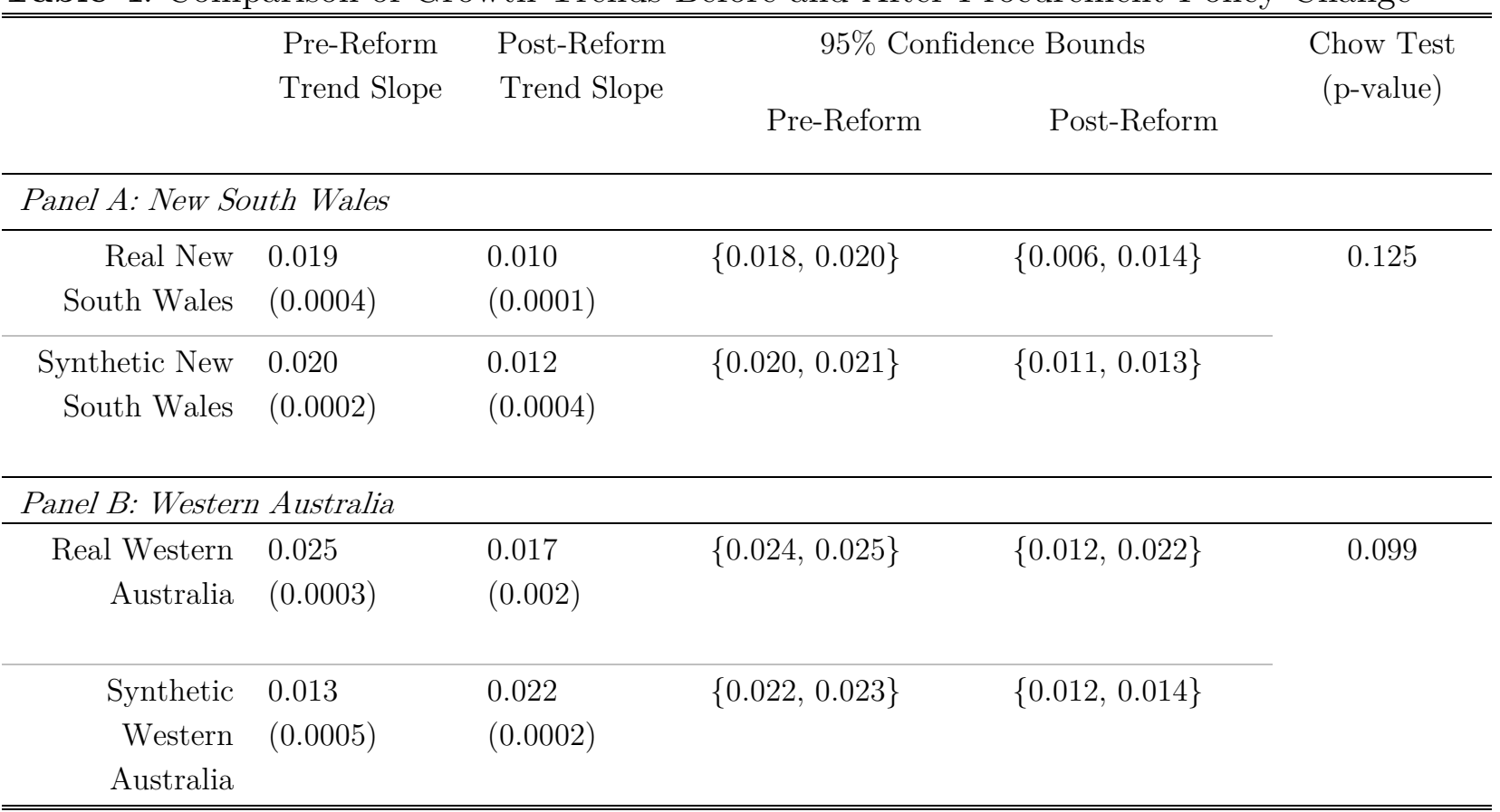

Figure 2: Economic Growth Trend Comparison Before and After E-Procurement Policy Change

(a) New South Wales


Figure 3: Balancing Economic Growth Trends

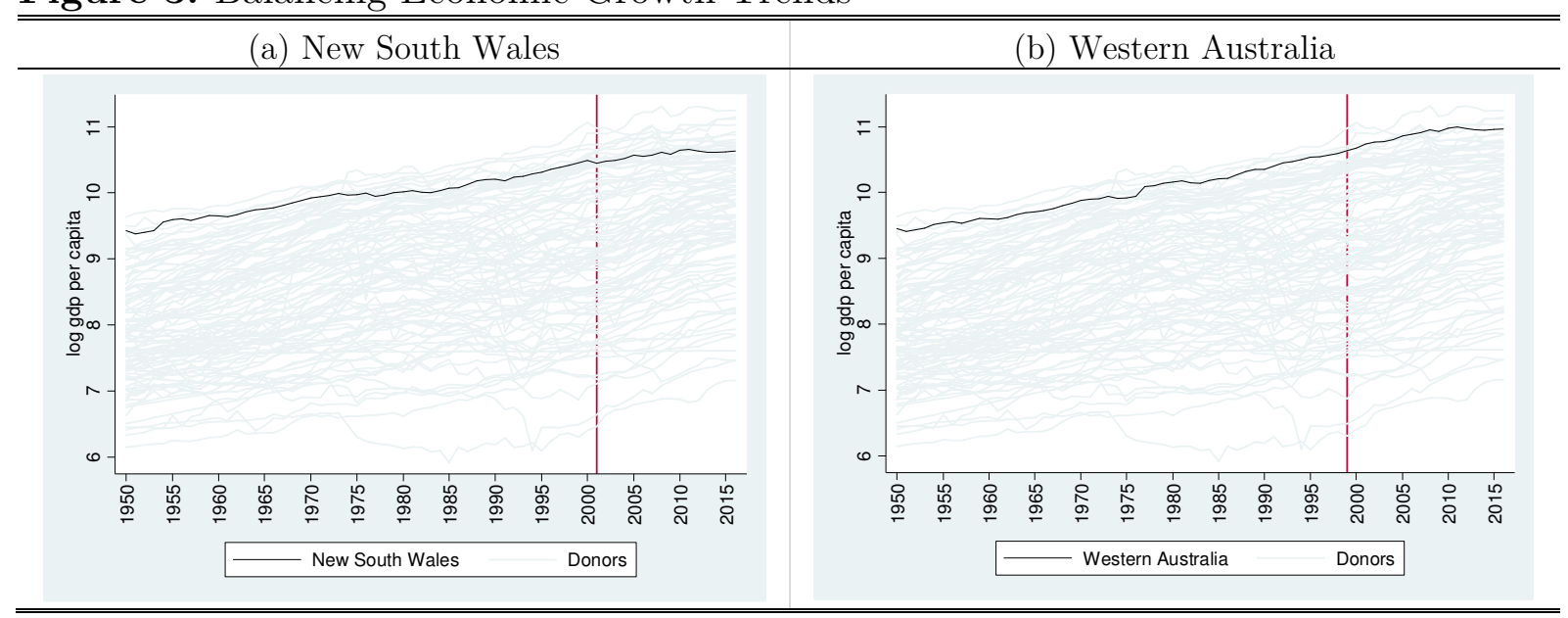


Figure 4: Economic Growth and Placebo Distribution in the Control Sample
(a) New South Wales
(b) Western Australia

Panel A: excluding countries with pre-reform RMSPE four times higher than the treated unit

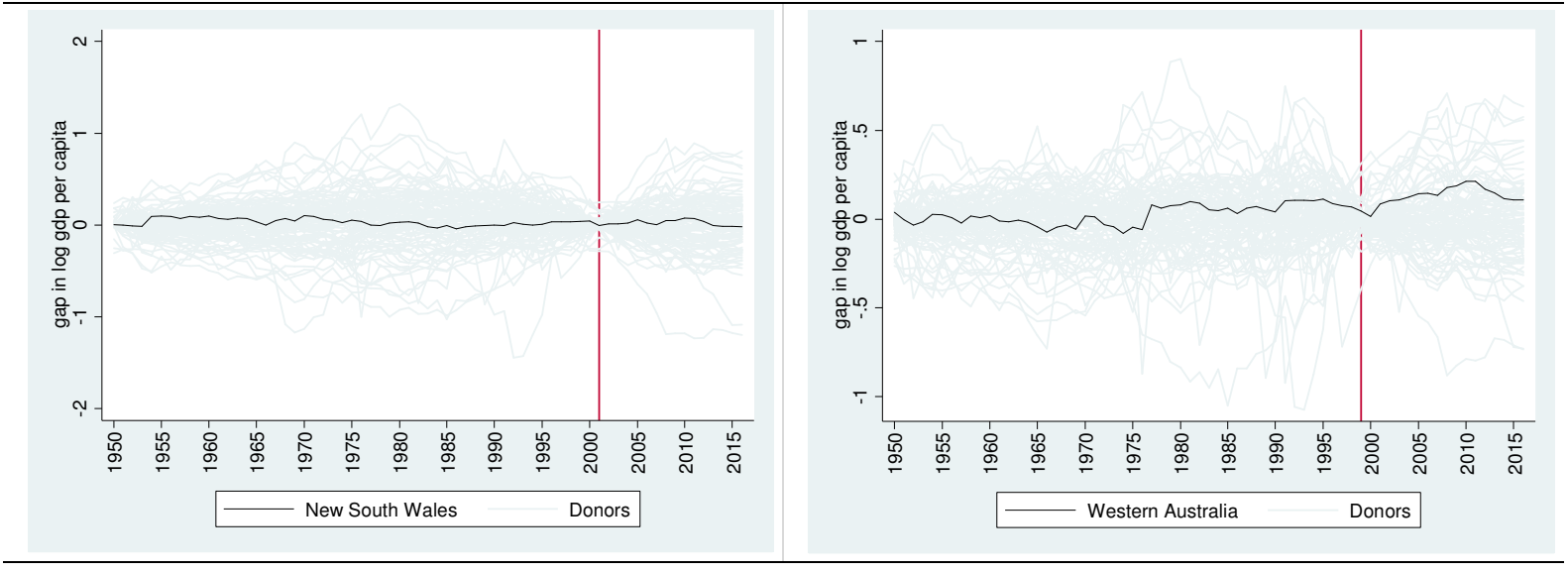

Panel B: excluding countries with pre-reform RMSPE five times higher than the treated unit

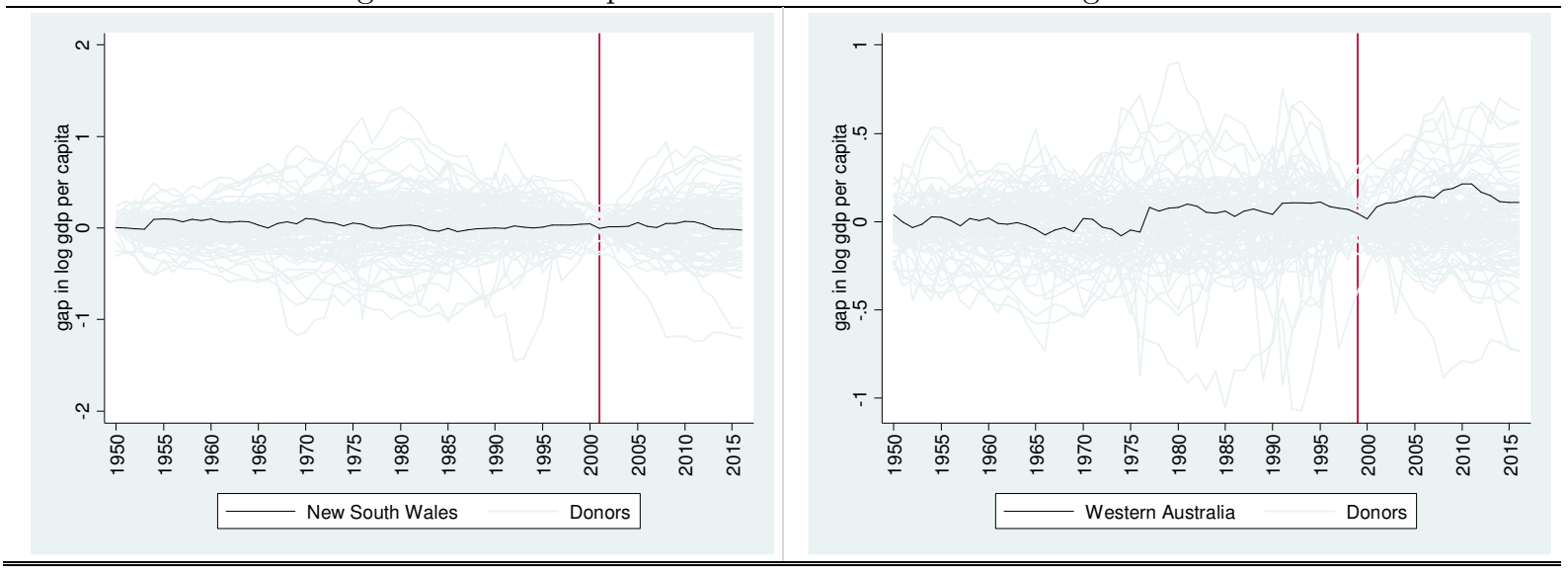


Figure 5: Randomization Inference on the Growth Effect of E-Procurement

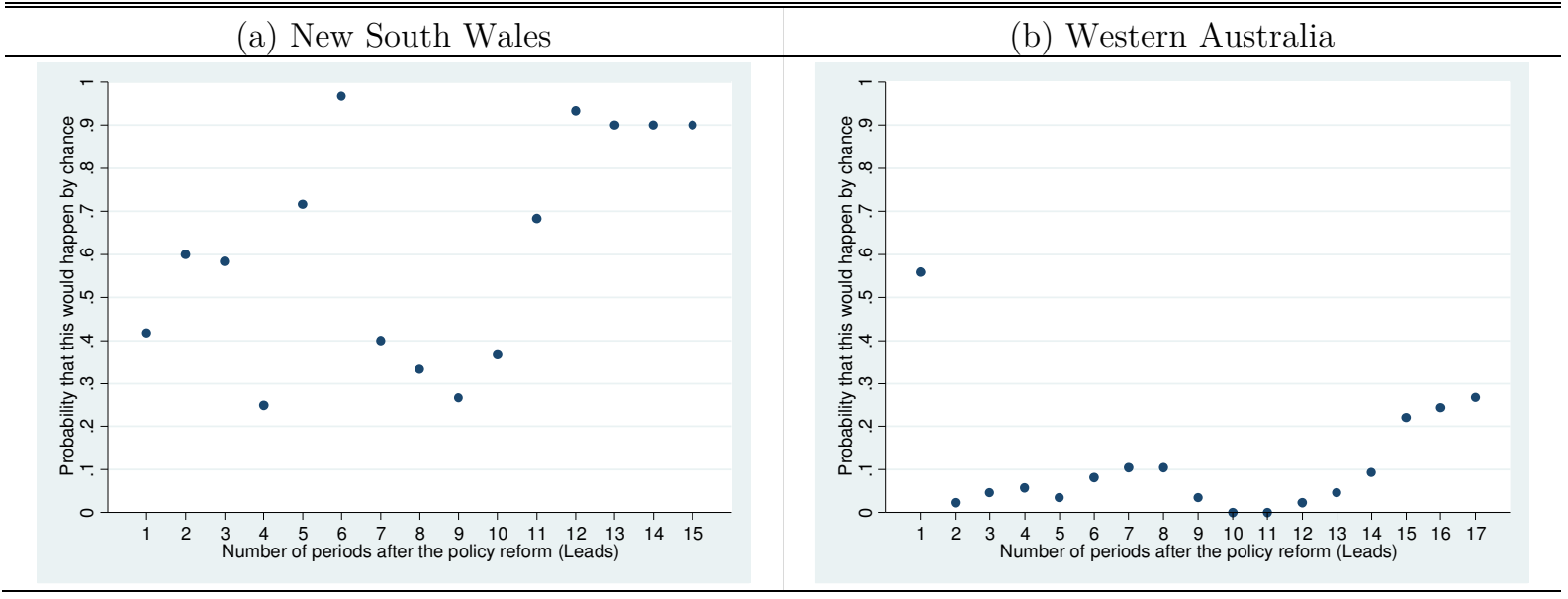

Figure 6: Falsely Assigned Policy Intervention Year

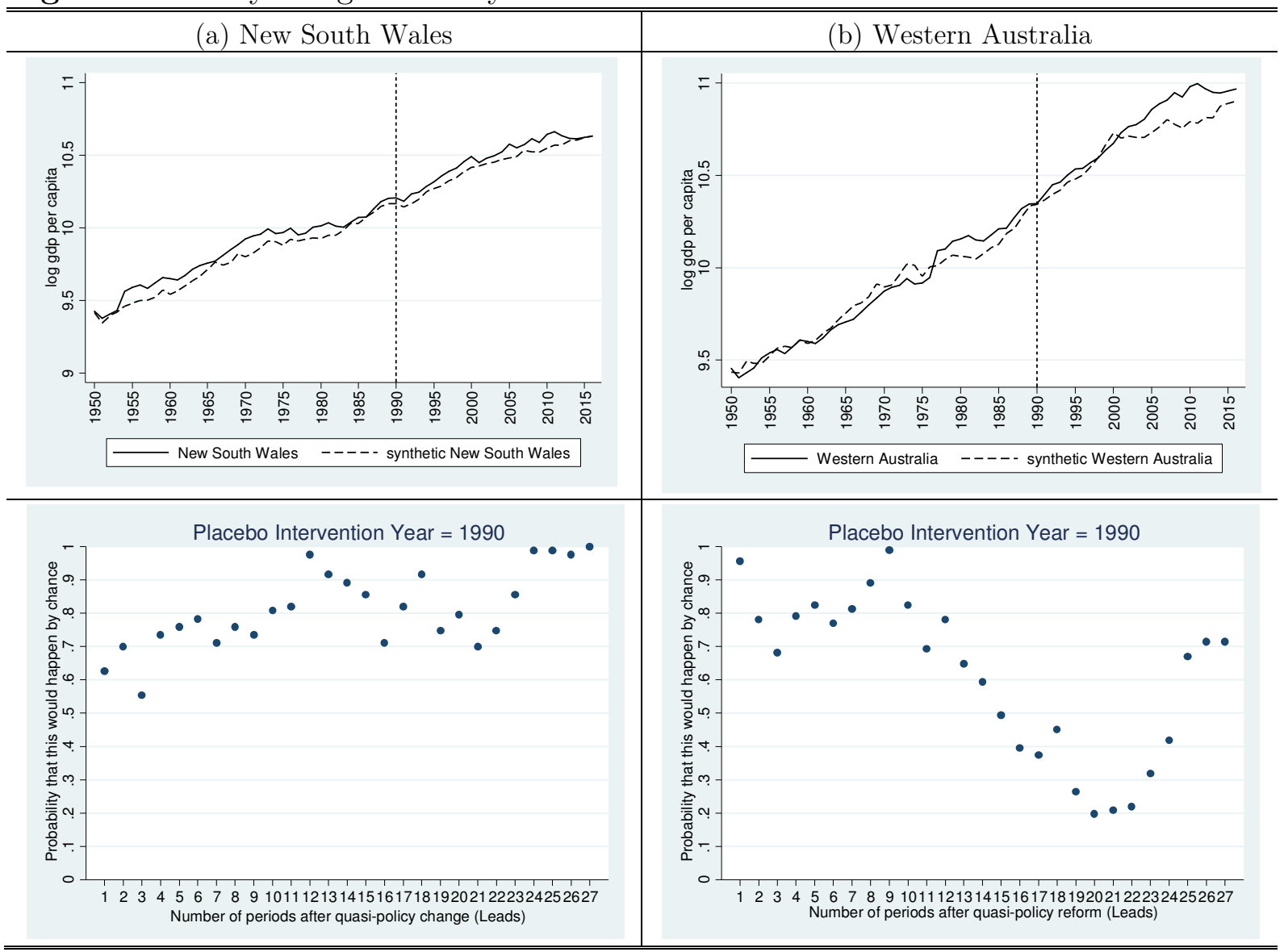


Table 5: Composition of Alternative Synthetic Control Groups for Western Australia and New South Wales

\begin{tabular}{|c|c|c|c|c|c|c|}
\hline & \multicolumn{3}{|c|}{ New South Wales (2002) } & \multicolumn{3}{|c|}{ Western Australia (2000) } \\
\hline & w/o US & $\begin{array}{l}\text { w/o New } \\
\text { Zealand }\end{array}$ & $\begin{array}{l}\text { w/o US } \\
\text { and New } \\
\text { Zealand }\end{array}$ & w/o US & $\begin{array}{l}\text { w/o New } \\
\text { Zealand }\end{array}$ & $\begin{array}{l}\text { w/o US and } \\
\text { New Zealand }\end{array}$ \\
\hline Root MSPE & 0.081 & 0.048 & 0.107 & 0.059 & 0.039 & 0.049 \\
\hline Albania & 0 & 0 & 0 & 0 & 0 & 0 \\
\hline Argentina & 0 & 0.249 & 0.232 & 0 & 0 & 0 \\
\hline Austria & 0 & 0 & 0 & 0 & 0 & 0 \\
\hline Bangladesh & 0 & 0 & 0 & 0 & 0 & 0 \\
\hline Belgium & 0 & 0 & 0 & 0 & 0 & 0 \\
\hline Bolivia & 0 & 0 & 0 & 0 & 0 & 0 \\
\hline Bosnia and & 0 & 0 & 0 & 0 & 0 & 0 \\
\hline \multicolumn{7}{|l|}{ Herzegovina } \\
\hline Botswana & 0 & 0 & 0 & 0 & 0 & 0 \\
\hline Brazil & 0 & 0 & 0 & 0 & 0 & 0 \\
\hline Bulgaria & 0 & 0 & 0 & 0 & 0 & 0 \\
\hline Cameroon & 0 & 0 & 0 & 0 & 0 & 0 \\
\hline Canada & 0.567 & 0.141 & 0.588 & 0.547 & 0.134 & 0.647 \\
\hline Cape Verde & 0 & 0 & 0 & 0 & 0 & 0 \\
\hline Chile & 0 & 0 & 0 & 0 & 0 & 0 \\
\hline China & 0 & 0 & 0 & 0 & 0 & 0 \\
\hline Colombia & 0 & 0 & 0 & 0 & 0 & 0 \\
\hline Costa Rica & 0 & 0 & 0 & 0 & 0 & 0 \\
\hline Cote d'Ivoire & 0 & 0 & 0 & 0 & 0 & 0 \\
\hline Croatia & 0 & 0 & 0 & 0 & 0 & 0 \\
\hline Cyprus & 0 & 0 & 0 & 0 & 0 & 0 \\
\hline Czech Republic & 0 & 0 & 0 & 0 & 0 & 0 \\
\hline Denmark & 0 & 0 & 0 & 0 & 0 & 0 \\
\hline Dominican & 0 & 0 & 0 & 0 & 0 & 0 \\
\hline \multicolumn{7}{|l|}{ Republic } \\
\hline Ecuador & 0 & 0 & 0 & 0 & 0 & 0 \\
\hline Egypt & 0 & 0 & 0 & 0 & 0 & 0 \\
\hline El Salvador & 0 & 0 & 0 & 0 & 0 & 0 \\
\hline Estonia & 0 & 0 & 0 & 0 & 0 & 0 \\
\hline Finland & 0 & 0 & 0 & 0 & 0 & 0 \\
\hline France & 0 & 0 & 0 & 0 & 0 & 0 \\
\hline Germany & 0 & 0 & 0 & 0 & 0 & 0 \\
\hline Ghana & 0 & 0 & 0 & 0 & 0 & 0 \\
\hline Greece & 0 & 0 & 0 & 0 & 0 & 0 \\
\hline Guatemala & 0 & 0 & 0 & 0 & 0 & 0 \\
\hline Honduras & 0 & 0 & 0 & 0 & 0 & 0 \\
\hline Hong Kong & 0 & 0 & 0 & 0 & 0 & 0 \\
\hline Hungary & 0 & 0 & 0 & 0 & 0 & 0 \\
\hline Iceland & 0 & 0 & 0 & 0 & 0 & 0 \\
\hline India & 0 & 0 & 0 & 0 & 0 & 0 \\
\hline Indonesia & 0 & 0 & 0 & 0 & 0 & 0 \\
\hline Iran & 0 & 0 & 0 & 0 & 0 & 0 \\
\hline
\end{tabular}




\begin{tabular}{|c|c|c|c|c|c|c|}
\hline Iraq & 0 & 0 & 0 & 0 & 0 & 0 \\
\hline Ireland & 0 & 0 & 0 & 0 & 0 & 0 \\
\hline Israel & 0 & 0 & 0 & 0 & 0 & 0 \\
\hline Italy & 0 & 0 & 0 & 0 & 0 & 0 \\
\hline Japan & 0 & 0 & 0 & 0 & 0 & 0 \\
\hline Jordan & 0 & 0 & 0 & 0 & 0 & 0 \\
\hline Kosovo & 0 & 0 & 0 & 0 & 0 & 0 \\
\hline Lebanon & 0 & 0 & 0 & 0 & 0 & 0 \\
\hline Luxembourg & 0.063 & 0.223 & 0.188 & 0.318 & 0.271 & 0.303 \\
\hline Macedonia & 0 & 0 & 0 & 0 & 0 & 0 \\
\hline Madagascar & 0 & 0 & 0 & 0 & 0 & 0 \\
\hline Malaysia & 0 & 0.004 & 0 & 0 & 0.071 & 0.002 \\
\hline Malta & 0 & 0 & 0 & 0 & 0 & 0 \\
\hline Mauritius & 0 & 0 & 0 & 0 & 0 & 0 \\
\hline Mexico & 0 & 0 & 0 & 0 & 0 & 0 \\
\hline Mongolia & 0 & 0 & 0 & 0 & 0 & 0 \\
\hline Montenegro & 0 & 0 & 0 & 0 & 0 & 0 \\
\hline Morocco & 0 & 0 & 0 & 0 & 0 & 0 \\
\hline Mozambique & 0 & 0 & 0 & 0 & 0 & 0 \\
\hline Namibia & 0 & 0 & 0 & 0 & 0 & 0 \\
\hline Nepal & 0 & 0 & 0 & 0 & 0 & 0 \\
\hline New Zealand & 0.370 & excluded & excluded & 0.091 & excluded & excluded \\
\hline Nicaragua & 0 & 0 & 0 & 0 & 0 & 0 \\
\hline Nigeria & 0 & 0 & 0 & 0 & 0 & 0 \\
\hline Norway & 0 & 0 & 0 & 0.045 & 0.057 & 0.048 \\
\hline Oman & 0 & 0 & 0 & 0 & 0 & 0 \\
\hline Panama & 0 & 0 & 0 & 0 & 0 & 0 \\
\hline Paraguay & 0 & 0 & 0 & 0 & 0 & 0 \\
\hline Peru & 0 & 0 & 0 & 0 & 0 & 0 \\
\hline Philippines & 0 & 0 & 0 & 0 & 0 & 0 \\
\hline Poland & 0 & 0 & 0 & 0 & 0 & 0 \\
\hline Portugal & 0 & 0 & 0 & 0 & 0 & 0 \\
\hline Puerto Rico & 0 & 0 & 0 & 0 & 0 & 0 \\
\hline Romania & 0 & 0 & 0 & 0 & 0 & 0 \\
\hline Russia & 0 & 0 & 0 & 0 & 0 & 0 \\
\hline Rwanda & 0 & 0 & 0 & 0 & 0 & 0 \\
\hline Saudi Arabia & 0 & 0 & 0 & 0 & 0 & 0 \\
\hline Senegal & 0 & 0 & 0 & 0 & 0 & 0 \\
\hline Serbia & 0 & 0 & 0 & 0 & 0 & 0 \\
\hline Singapore & 0 & 0 & 0 & 0 & 0 & 0 \\
\hline Slovakia & 0 & 0 & 0 & 0 & 0 & 0 \\
\hline Slovenia & 0 & 0 & 0 & 0 & 0 & 0 \\
\hline South Africa & 0 & 0 & 0 & 0 & 0 & 0 \\
\hline South Korea & 0 & 0 & 0 & 0 & 0 & 0 \\
\hline Spain & 0 & 0 & 0 & 0 & 0 & 0 \\
\hline Sweden & 0 & 0 & 0 & 0 & 0 & 0 \\
\hline Switzerland & 0 & 0 & 0 & 0 & 0 & 0 \\
\hline Syria & 0 & 0 & 0 & 0 & 0 & 0 \\
\hline Thailand & 0 & 0 & 0 & 0 & 0 & 0 \\
\hline
\end{tabular}




\begin{tabular}{rcccccc} 
The Netherlands & 0 & 0 & 0 & 0 & 0 & 0 \\
Trinidado and & 0 & 0 & 0 & 0 & 0 & 0 \\
Tobago & & & & & & \\
Tunisia & 0 & 0 & 0 & 0 & 0 & 0 \\
Turkey & 0 & 0 & 0 & 0 & 0 & 0 \\
Ukraine & 0 & 0 & 0 & 0 & 0 & 0 \\
United Kingdom & 0 & 0 & 0 & 0 & 0 & 0 \\
United States & excluded & 0.383 & excluded & excluded & 0.468 & excluded \\
Uruguay & 0 & 0 & 0 & 0 & 0 & 0 \\
Venezuela & 0 & 0 & 0 & 0 & 0 & 0 \\
Vietnam & 0 & 0 & 0 & 0 & 0 & 0 \\
Zambia & 0 & 0 & 0 & 0 & 0 & 0 \\
Zimbabwe & 0 & 0 & 0 & 0 & 0 & 0 \\
\hline \hline
\end{tabular}


Figure 7: Economic Growth Effect of E-Procurement with Alternative Synthetic Control Groups
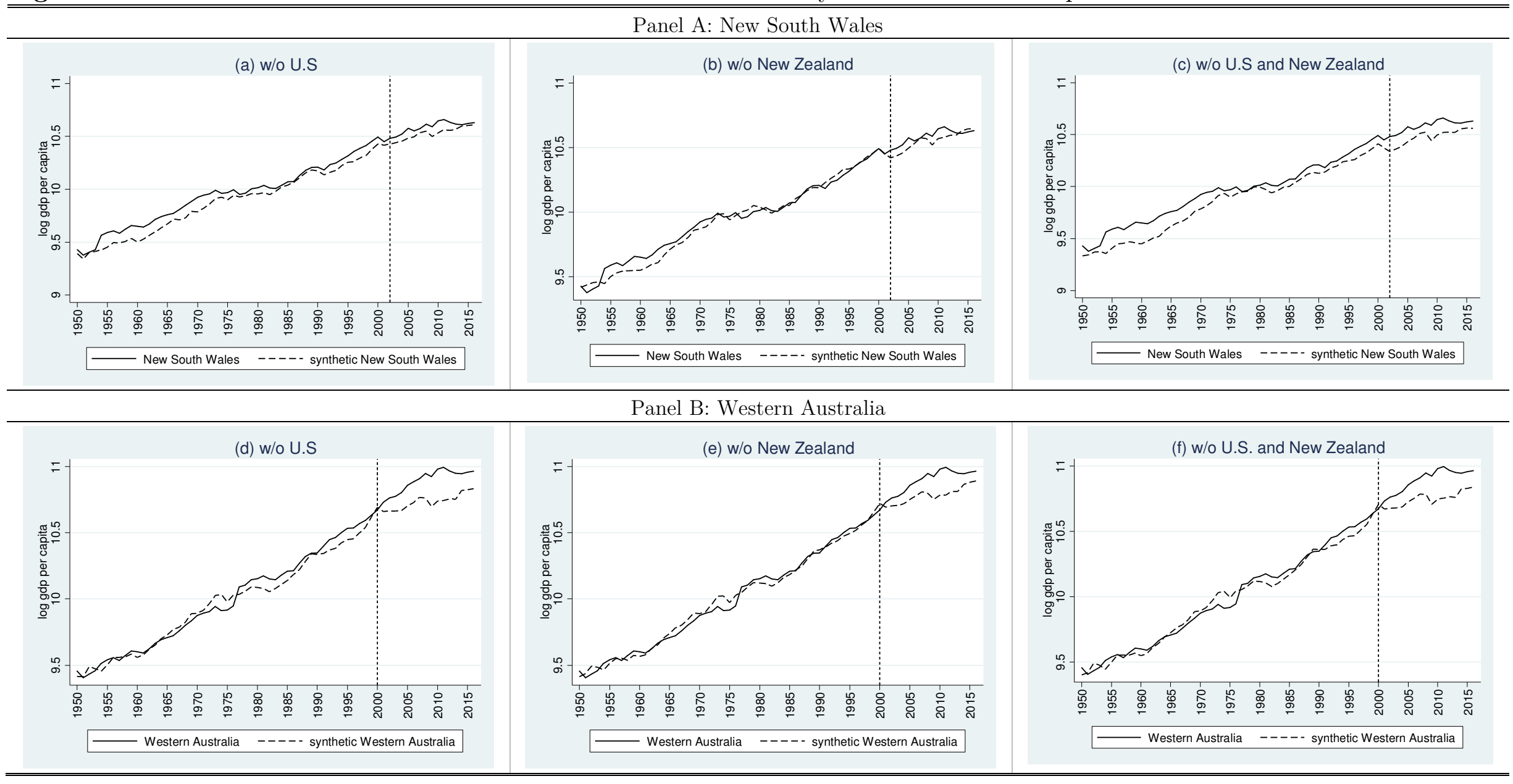
Figure 8: Economic Growth Effect of E-Procurement with Shorter Pre-Treatment Time Span and Country-Level Control Sample

(a) Baseline effect

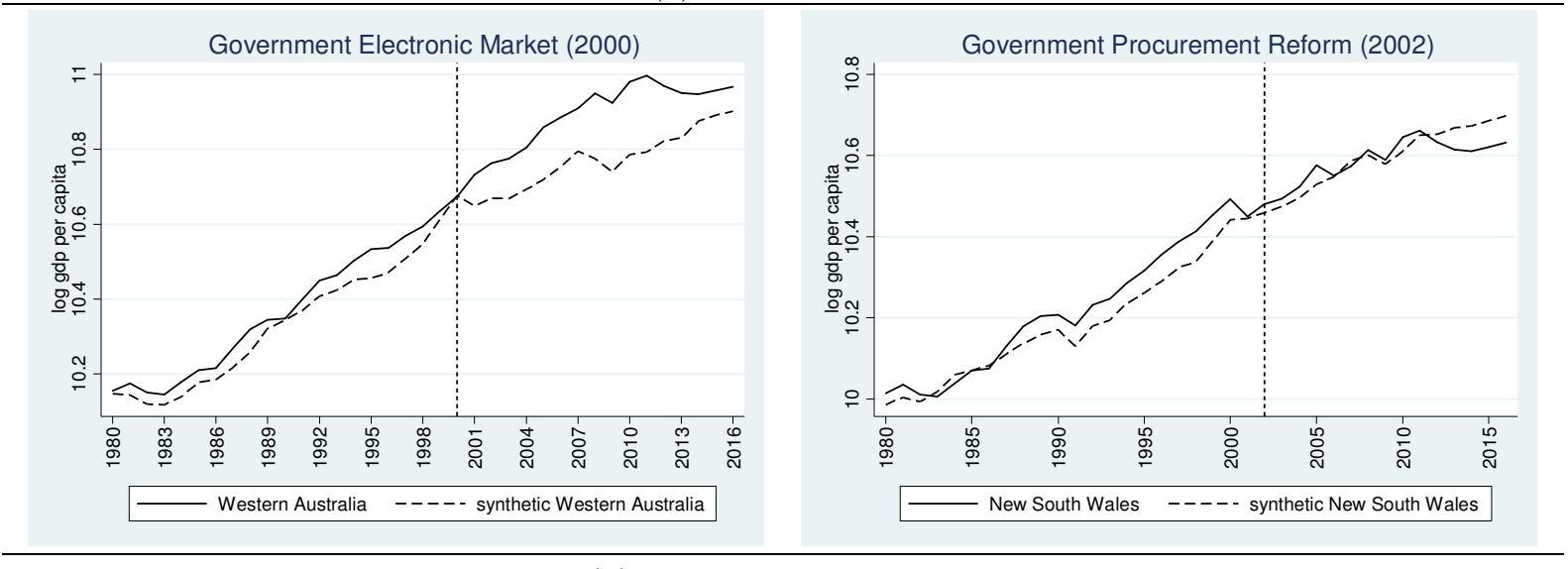

(b) In-space placebo check

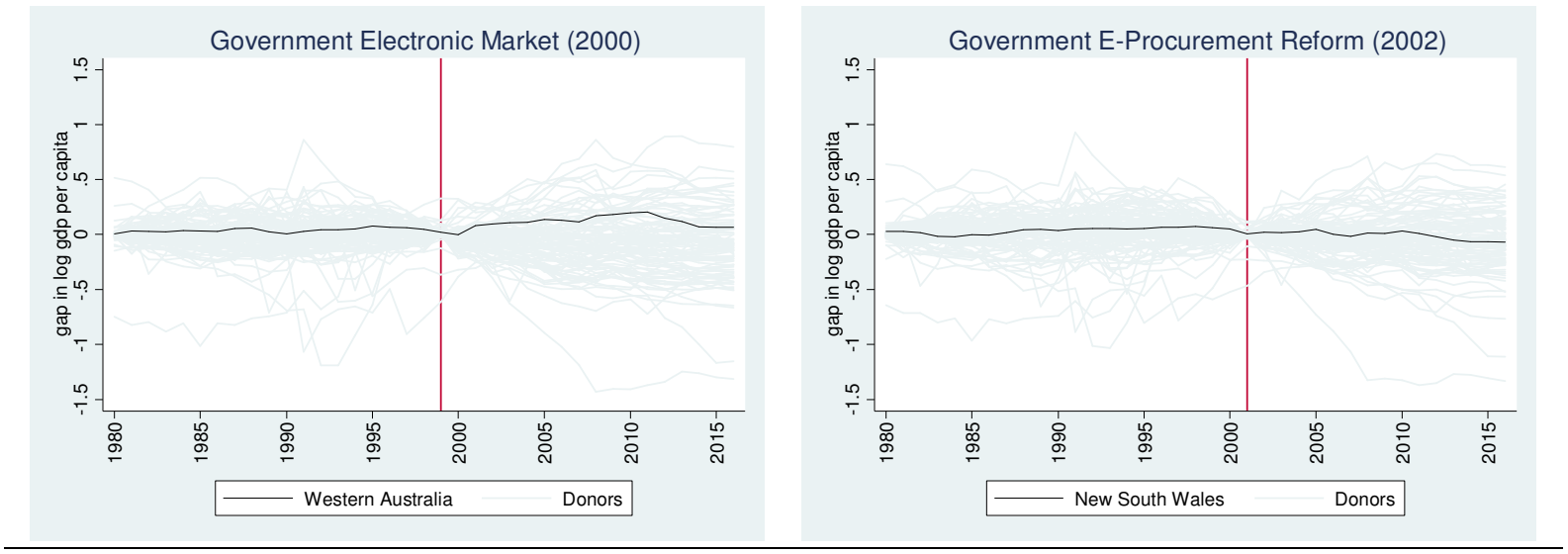

(c) Randomization inference
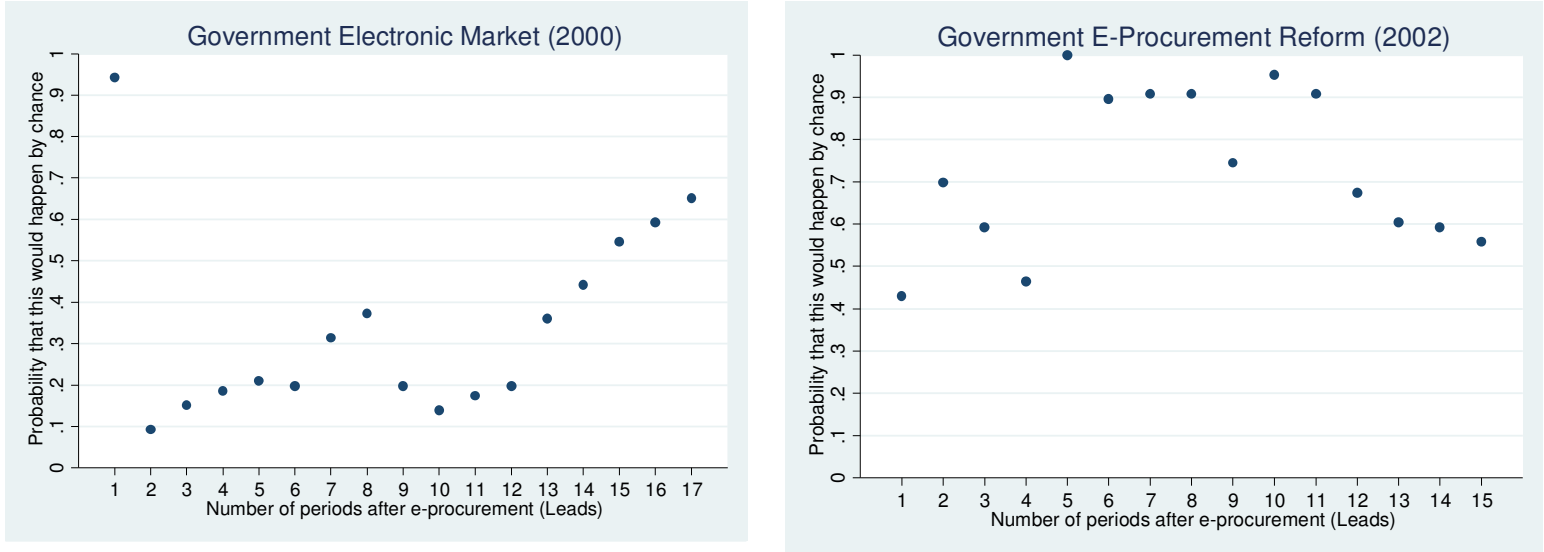
Table 6: Composition of Synthetic Control Groups with Shorter Pre-Treatment Period

\begin{tabular}{|c|c|c|}
\hline & New South Wales (2002) & Western Australia (2000) \\
\hline Root MSPE & 0.052 & 0.042 \\
\hline Implied per capita GDP & $-8 \%$ & $+6 \%$ \\
\hline gap & & \\
\hline Albania & 0 & 0 \\
\hline Argentina & 0 & 0 \\
\hline Austria & 0 & 0 \\
\hline Bangladesh & 0 & 0 \\
\hline Belgium & 0 & 0 \\
\hline Bolivia & 0 & 0 \\
\hline Bosnia and Herzegovina & 0 & 0 \\
\hline Botswana & 0 & 0 \\
\hline Brazil & 0 & 0 \\
\hline Bulgaria & 0 & 0 \\
\hline Cameroon & 0 & 0 \\
\hline Canada & 0 & 0 \\
\hline Cape Verde & 0 & 0 \\
\hline Chile & 0 & 0 \\
\hline China & 0 & 0 \\
\hline Colombia & 0 & 0 \\
\hline Costa Rica & 0 & 0 \\
\hline Cote d'Ivoire & 0 & 0 \\
\hline Croatia & 0 & 0 \\
\hline Cyprus & 0 & 0 \\
\hline Czech Republic & 0 & 0 \\
\hline Denmark & 0 & 0 \\
\hline Dominican Republic & 0 & 0 \\
\hline Ecuador & 0 & 0 \\
\hline Egypt & 0 & 0 \\
\hline El Salvador & 0 & 0 \\
\hline Estonia & 0 & 0 \\
\hline Finland & 0 & 0 \\
\hline France & 0 & 0 \\
\hline Germany & 0 & 0 \\
\hline Ghana & 0 & 0 \\
\hline Greece & 0 & 0 \\
\hline Guatemala & 0 & 0 \\
\hline Honduras & 0 & 0 \\
\hline Hong Kong & 0 & 0.075 \\
\hline Hungary & 0 & 0 \\
\hline Iceland & 0 & 0 \\
\hline India & 0 & 0 \\
\hline Indonesia & 0 & 0 \\
\hline Iran & 0 & 0 \\
\hline Iraq & 0 & 0 \\
\hline Ireland & 0 & 0 \\
\hline Israel & 0 & 0 \\
\hline Italy & 0 & 0 \\
\hline
\end{tabular}




\begin{tabular}{|c|c|c|}
\hline Japan & 0 & 0 \\
\hline Jordan & 0 & 0 \\
\hline Kosovo & 0 & 0 \\
\hline Lebanon & 0 & 0 \\
\hline Luxembourg & 0 & 0.308 \\
\hline Macedonia & 0 & 0 \\
\hline Madagascar & 0 & 0 \\
\hline Malaysia & 0 & 0 \\
\hline Malta & 0 & 0 \\
\hline Mauritius & 0 & 0 \\
\hline Mexico & 0 & 0 \\
\hline Mongolia & 0 & 0 \\
\hline Montenegro & 0 & 0 \\
\hline Morocco & 0 & 0 \\
\hline Mozambique & 0 & 0 \\
\hline Namibia & 0 & 0 \\
\hline Nepal & 0 & 0 \\
\hline New Zealand & 0.505 & 0.081 \\
\hline Nicaragua & 0 & 0 \\
\hline Nigeria & 0 & 0 \\
\hline Norway & 0.100 & 0 \\
\hline Oman & 0 & 0 \\
\hline Panama & 0 & 0 \\
\hline Paraguay & 0 & 0 \\
\hline Peru & 0 & 0 \\
\hline Philippines & 0 & 0 \\
\hline Poland & 0 & 0 \\
\hline Portugal & 0 & 0 \\
\hline Puerto Rico & 0 & 0 \\
\hline Romania & 0 & 0 \\
\hline Russia & 0 & 0 \\
\hline Rwanda & 0 & 0 \\
\hline Saudi Arabia & 0.037 & 0.119 \\
\hline Senegal & 0 & 0 \\
\hline Serbia & 0 & 0 \\
\hline Singapore & 0 & 0 \\
\hline Slovakia & 0 & 0 \\
\hline Slovenia & 0 & 0 \\
\hline South Africa & 0 & 0 \\
\hline South Korea & 0 & 0 \\
\hline Spain & 0 & 0 \\
\hline Sweden & 0 & 0 \\
\hline Switzerland & 0 & 0 \\
\hline Syria & 0 & 0 \\
\hline Thailand & 0 & 0 \\
\hline e Netherlands & 0 & 0 \\
\hline lo and Tobago & 0 & 0 \\
\hline Tunisia & 0 & 0 \\
\hline Turkey & 0 & 0 \\
\hline
\end{tabular}




\begin{tabular}{rcc} 
Ukraine & 0 & 0 \\
United Kingdom & 0 & 0 \\
United States & 0.359 & 0.417 \\
Uruguay & 0 & 0 \\
Venezuela & 0 & 0 \\
Vietnam & 0 & 0 \\
Zambia & 0 & 0 \\
Zimbabwe & 0 & 0 \\
\hline \hline
\end{tabular}


Figure 9: Economic Growth Effect of E-Procurement with Shorter Pre-Treatment Time Span and Region-Level Control Sample

(a) Baseline effect

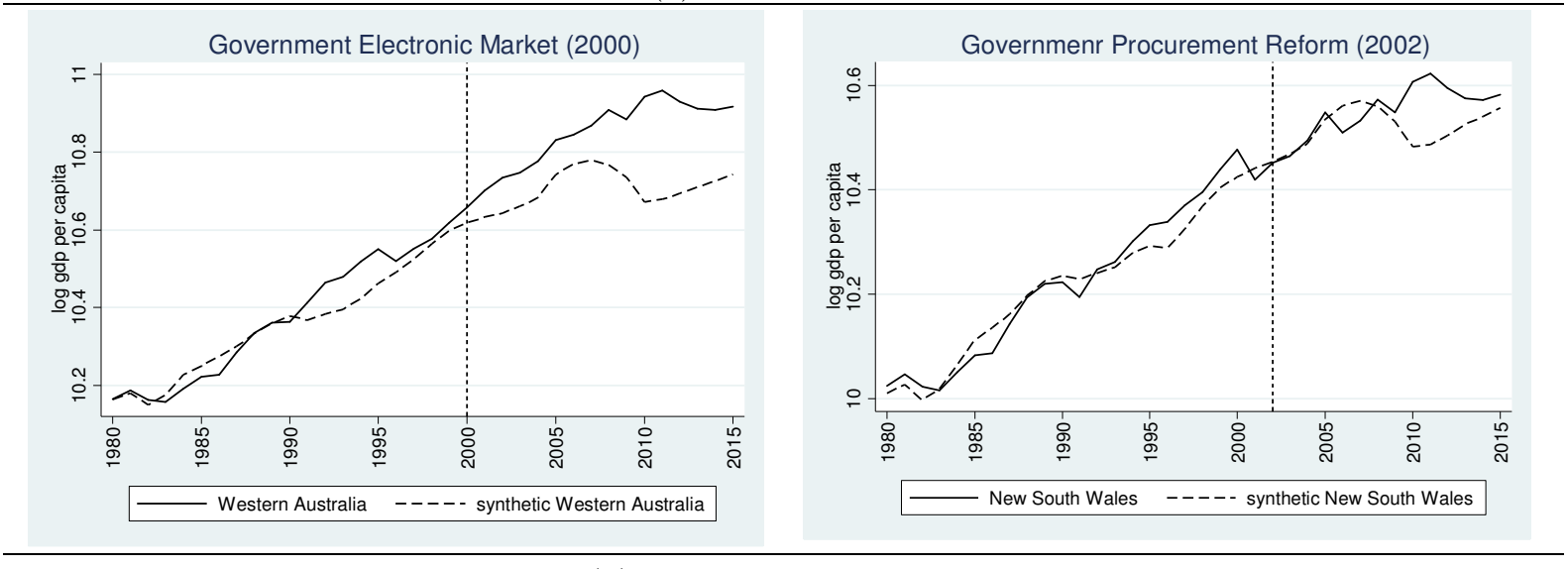

(b) In-space placebo check

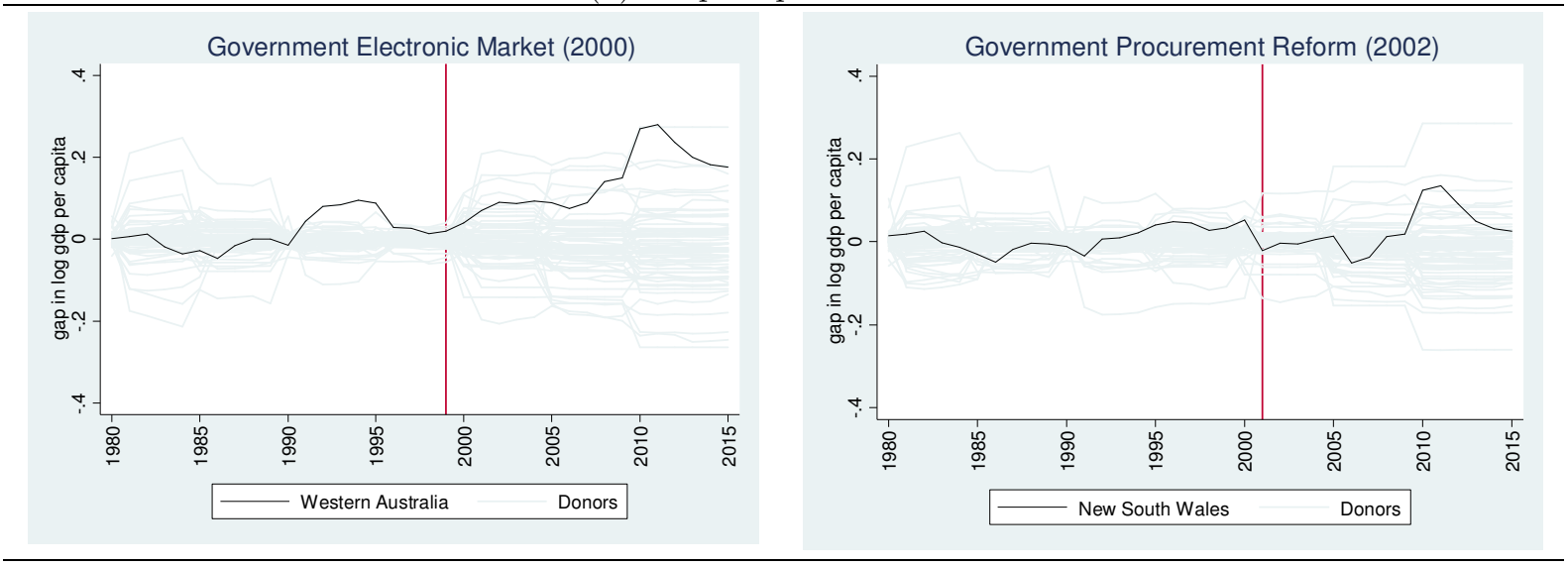

(c) Randomization inference

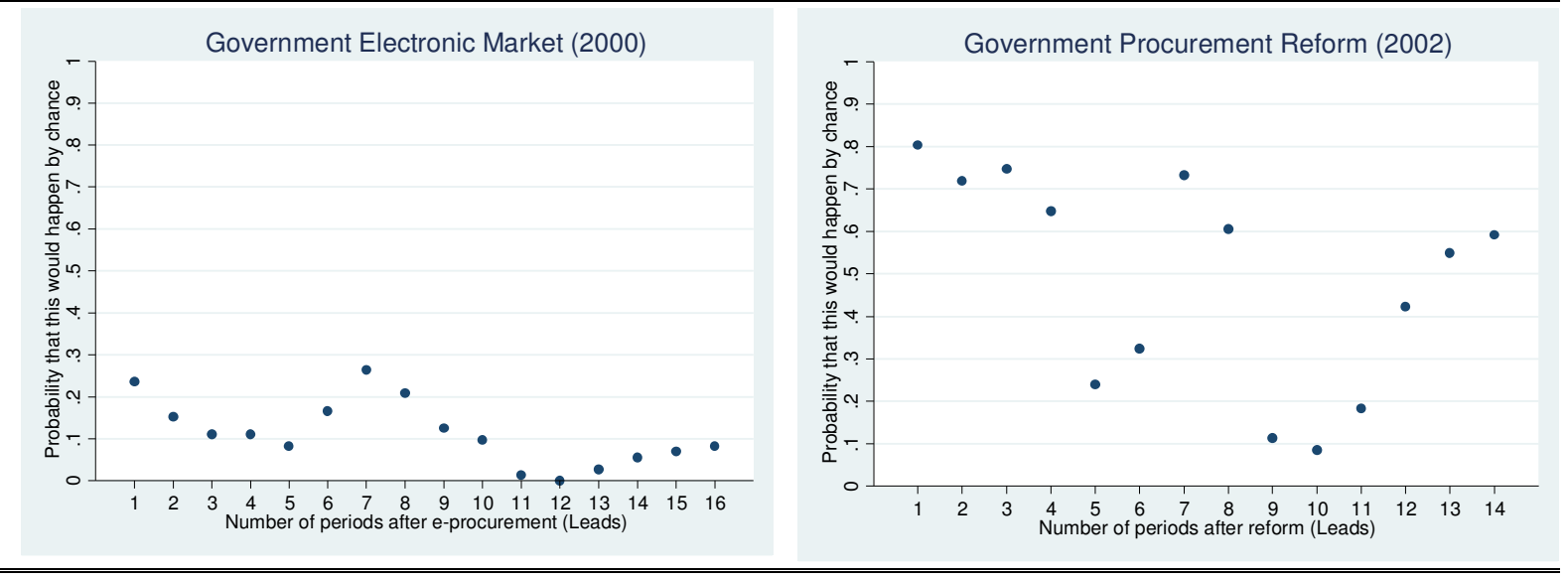


Table 7: Composition of Synthetic Control Groups with Shorter Pre-Treatment Period and Region-Level Control Sample

\begin{tabular}{|c|c|c|}
\hline & New South Wales (2002) & Western Australia (2000) \\
\hline Root MSPE & 0.032 & 0.044 \\
\hline Implied per capita GDP gap & $-2 \%$ & $+18 \%$ \\
\hline Alabama & 0 & 0 \\
\hline Alaska & 0 & 0 \\
\hline Arizona & 0 & 0 \\
\hline Arkansas & 0 & 0 \\
\hline California & 0 & 0 \\
\hline Colorado & 0 & 0 \\
\hline Connecticut & 0 & 0 \\
\hline District of Columbia & 0 & 0.14 \\
\hline Delaware & 0 & 0 \\
\hline Florida & 0.69 & 0.15 \\
\hline Georgia & 0 & 0.19 \\
\hline Hawaii & 0 & 0 \\
\hline Iowa & 0 & 0 \\
\hline Idaho & 0 & 0 \\
\hline Illinois & 0 & 0 \\
\hline Indiana & 0 & 0 \\
\hline Kansas & 0 & 0 \\
\hline Kentucky & 0 & 0 \\
\hline Louisiana & 0 & 0 \\
\hline Massachusettes & 0 & 0 \\
\hline Maryland & 0 & 0 \\
\hline Maine & 0 & 0 \\
\hline Michigan & 0.02 & 0 \\
\hline Minnesota & 0 & 0 \\
\hline Missouri & 0 & 0 \\
\hline Mississippi & 0 & 0 \\
\hline Montana & 0 & 0 \\
\hline North Carolina & 0 & 0 \\
\hline North Dakota & 0 & 0 \\
\hline Nebraska & 0 & 0 \\
\hline New Hampshire & 0 & 0 \\
\hline New Jersey & 0 & 0 \\
\hline New Mexico & 0 & 0 \\
\hline Nevada & 0 & 0.35 \\
\hline New York & 0 & 0 \\
\hline Ohio & 0 & 0 \\
\hline Oklahoma & 0 & 0 \\
\hline Oregon & 0 & 0 \\
\hline Pennsylvania & 0 & 0 \\
\hline Rhode Island & 0 & 0 \\
\hline South Carolina & 0 & 0 \\
\hline South Dakota & 0 & 0 \\
\hline Tennessee & 0 & 0 \\
\hline Texas & 0 & 0 \\
\hline
\end{tabular}




\begin{tabular}{|c|c|c|}
\hline Utah & 0 & 0 \\
\hline Virginia & 0 & 0 \\
\hline Vermont & 0 & 0 \\
\hline Wisconsin & 0 & 0 \\
\hline West Virginia & 0 & 0 \\
\hline Wyoming & 0 & 0 \\
\hline Alberta & 0 & 0 \\
\hline British Columbia & 0 & 0 \\
\hline Manitoba & 0 & 0 \\
\hline New Brunswick & 0 & 0 \\
\hline Newfoundland-Labrador & 0 & 0 \\
\hline Nova Scotia & 0 & 0 \\
\hline Ontario & 0 & 0 \\
\hline Prince Edward Island & 0 & 0 \\
\hline Quebec & 0 & 0 \\
\hline Saskatchewan & 0 & 0 \\
\hline Yukon and Nunavut & 0 & 0 \\
\hline East Anglia & 0.06 & 0 \\
\hline Midlands & 0 & 0 \\
\hline North England & 0 & 0 \\
\hline North West England & 0 & 0 \\
\hline Northern Ireland & 0 & 0 \\
\hline Scotland & 0 & 0 \\
\hline South East England with London & 0 & 0.17 \\
\hline South West England & 0 & 0 \\
\hline Wales & 0.23 & 0 \\
\hline Yorkshire & 0 & 0 \\
\hline
\end{tabular}


Figure 10: percentile rank of the per capita GDP gap

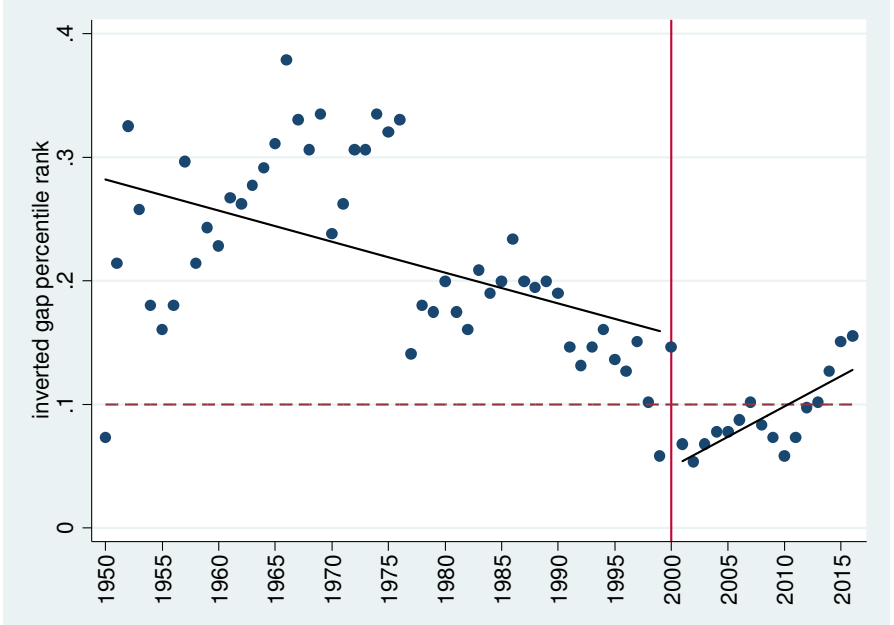

Figure 11: E-Procurement Impact vs. Mining Boom in Western Australia

(a) Baseline effect

E-procurement

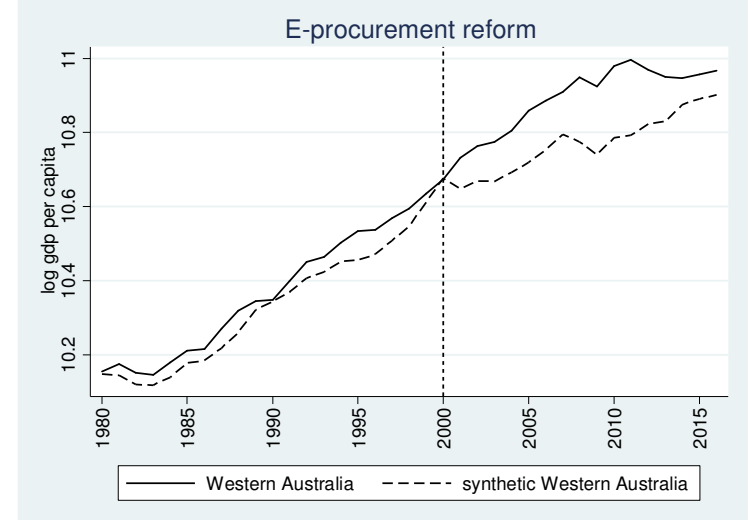

Mining boom

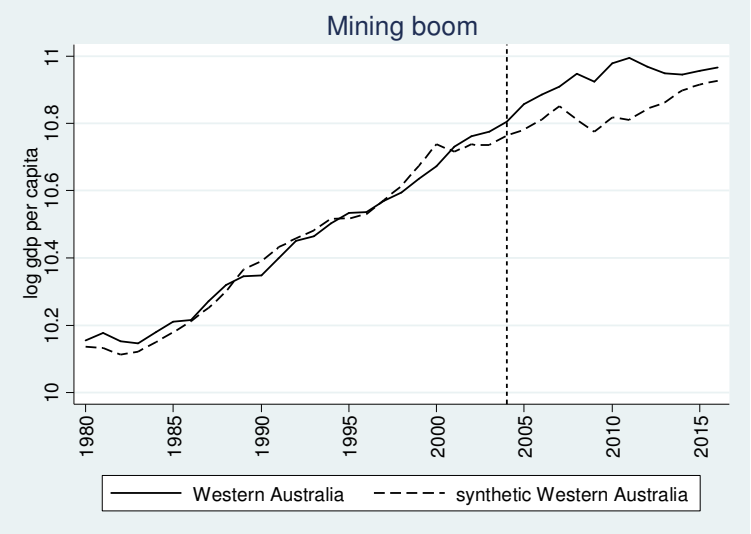

(b) p-values

\section{E-procurement}

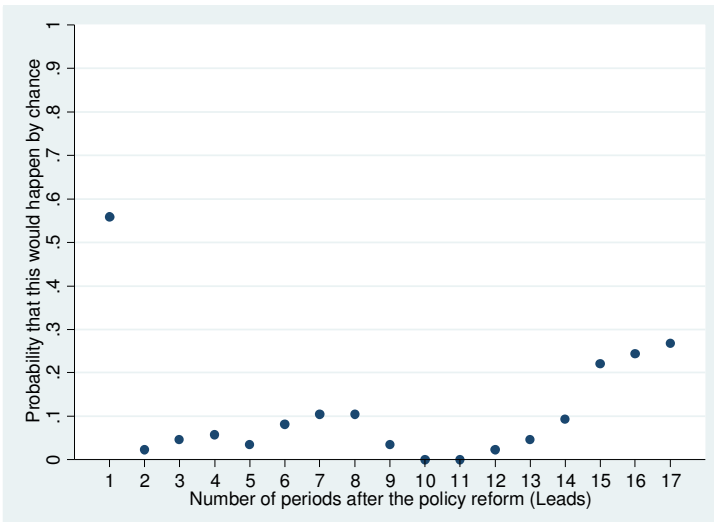

Mining boom

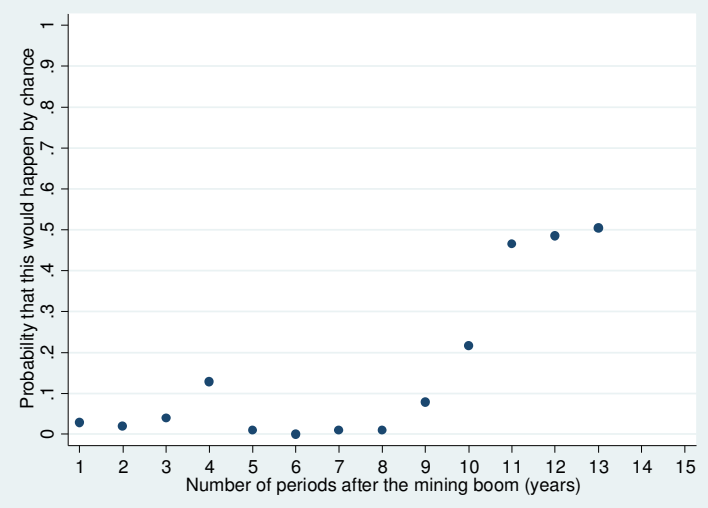

